\title{
The Impact of Regulations on Compliance Costs, Risk-taking, and Reporting Quality of the EU Banks
}

Sunil Poshakwale, Daniel Aghanya and Vineet Agarwal

\begin{abstract}
$\underline{\text { Abstract }}$
The paper examines how the Statutory Audit and Corporate Reporting Directives (SACORD) affect the compliance costs, risk taking and quality of financial reporting of the EU banks. Using a natural experiment, we find that post SACORD, both compliance costs and risk taking increase significantly. However, the implementation of additional regulations seems to be effective in terms of improved quality of financial reporting. When we analyse the impact by size, we find that smaller banks face disproportionately higher increase in compliance costs while larger banks seem to engage in greater risk taking.
\end{abstract}

Keywords: Financial regulation; Transparency; Financial system; Financial stability; Difference-in-differences.

JEL Classification: G18, G21 
The importance of regulation for ensuring an effective financial system is extensively discussed in the extant literature (see e.g. Klomp \& Haan, 2012). A key objective of financial regulation is to enhance the functioning of the financial system so that it is able to absorb shocks and maintain financial stability as disruptions can potentially have severe real economic effects (Acharya \& Ryan, 2016). The European Parliament and the Council of the European Union issued the directive 2006/43/EC (SAD) which aims to harmonise statutory audit processes across the European Union (EU) member states. Further, another directive 2006/46/EC (CRD) was issued which primarily deals with credible financial reporting. The regulations aim to harmonise the auditing standards and demand greater external oversight by the statutory auditors. The auditors are required to follow the International Auditing Standards (IAS), report on the appropriateness of internal controls, and verify that a corporate governance statement is included in the annual report. In addition, the directives require greater disclosures of Off Balance Sheet (OBS) and the Related Party Transactions (RPTs). These regulatory requirements are expected to have significant financial and investment implications for the EU firms. The additional scrutiny required by these regulations will need significantly more audit work which in turn is likely to increase the audit fee. Further, increased oversight of internal control systems and greater disclosures required by the regulations should lead to less risk taking and improved financial reporting.

The need for effective regulation of the banking system arises because market participants are exposed to asymmetric information. A number of studies show that increased disclosures reduce information asymmetry and improve the information environment by providing investors equal access to information (Leuz \& Verrecchia, 2000). However, the 
existing literature also highlights that cost-benefit analysis of regulation is necessary to understand its economic consequences (e.g., LaFond \& You, 2010). This paper empirically examines the impact of the Statutory Audit and Corporate Reporting Directives (SACORD hereafter) on the compliance costs, risk taking and quality of financial reporting of the EU banks.

There are several important reasons why we focus our research on banks. First, the 2007-08 financial crisis has clearly shown that banks play a central role in the financial system and have an unambiguous relation with systemic risk (e.g., Mohsni and Otchere, 2018). Also, banks are main issuers of guaranteed deposits and providers of liquidity in the economy, their key role in the smooth running of the financial system cannot be overemphasised. Second, despite their critical role in the global economy, ${ }^{1}$ previous research on the impact of disclosure regulations ignores banks due to their unique features (e.g., Bargeron et al., 2010; Iliev, 2010; De George et al., 2013). Third, the financial statements of banks are characterised by complex transactions and lack transparency (Flannery et al., 2013). The complexity of bank's business models (e.g., Flannery et al., 2013) renders accurate pricing of riskiness of bank assets more challenging (e.g., Cordella and Yeyati, 1998) which could dissuade banks from lowering risk taking. Finally, although SACORD regulations apply to all public listed firms in the EU, some of its provisions have greater implications for the banking sector. We discuss these relevant articles of the SACORD regulations in the next section.

The extant literature is unanimous on the issue that regulations increase compliance costs. For instance, Iliev (2010) reports 74 to 87 percent increase in the compliance costs for

\footnotetext{
${ }^{1}$ The combined assets of the EU banks represent about half of global banking assets with branches and subsidiaries around the world (Lehmann \& Nyberg, 2014). According to a report by the European Banking Federation (2018), by the end of 2017, EU-28 banks employed about 2.7 million people. Hence the impact of emerging regulations on the EU banks has global implications.
} 
the US firms following the SOX regulation. Pasiouras et al. (2009) examine the impact of banking regulations related with market discipline and capital requirements. They show that regulations which enhance market discipline increase both profit and cost efficiency of banks globally. However, regulations on capital requirements improves cost efficiency but reduce profit efficiency. Further, De George et al. (2013) find 23 percent increase in the audit costs of the Australian firms after the introduction of the International Financial Reporting Standards (IFRS). Our paper contributes to this strand of literature by offering empirical evidence of the impact of the SACORD on compliance costs of the EU banks.

In contrast, the evidence of the effects of regulations on risk taking is mixed. One strand of the literature posits that increased disclosure can reduce bank risk-taking through outside discipline (e.g., Bushman \& Williams, 2012). For instance, Akhigbe et al. (2016) find evidence which suggests a decline in risk taking by banks and financial institutions following the introduction of the Dodd-Frank regulation. On the other hand, some studies report a positive association between regulation and bank risk-taking. There is evidence which suggests that illiquid and harder to observe nature of banks' portfolios make it difficult for the market to discipline risk-taking (Flannery et al., 2013), spurring bank managers to take more risks. Moreno and Takalo (2016) propose a theoretical model and argue that despite the benefits of increased disclosures, the associated costs of regulations impose a significant financial burden which can influence banks to take more risks. Given the inconclusive evidence, more research on the impact of regulation on risk-taking is required (Acharya \& Ryan, 2016). As SACORD is an EU-wide regulation, a thorough investigation of its effects on the risk-taking by the EU banks will offer rich insights to the regulators and other stakeholders.

Another key objective of the SACORD is to improve quality of financial reporting. There is considerable evidence that disclosure regulations improve quality of financial 
information (e.g., Barth et al, 2008). Barakat and Hussainey (2013) find that banks operating under regulations that promote competition provide higher operational risk disclosures. Papadamou and Tzivinikos (2013) find that adoption of International Financial Reporting Standards (IFRS) improves the information content of financial statements of Greek banks. However, there is evidence to the contrary which suggests that increased disclosure requirements can lead to a decline in the reporting quality as banks respond by changing assets composition and their classification in the financial reports (Thakor, 2015). Given the contradictory evidence in the extant literature, we investigate whether the SACORD regulations have improved the quality of financial reporting. A robust evidence of the impact on the reporting quality will be highly valuable to the regulators in understanding the effectiveness of the regulations.

Our paper makes novel contributions by providing evidence on the costs and benefits of new EU regulations that are a part of the Financial Services Actions Plan (FSAP). Specifically, we make three-fold contribution. First, we contribute to the literature on the impact of financial regulation on compliance costs (e.g., Bargeron et al., 2010; Iliev, 2010; De George et al., 2013). While most papers consider only non-banking firms, to the best of our knowledge, this is the first study to provide evidence of impact of SACORD on compliance costs of EU banks. Second, some studies have shown that regulation lowers bank risk taking (e.g., Bushman \& Williams, 2012; Akhigbe et al., 2016). However, as argued by Goldstein and Sapra (2013), and Moreno and Takalo (2016), increased regulations which require banks to increase transparency can incentivise banks to take more risks. We contribute to this debate on disclosure regulations and its effect on bank risk taking. Third, the existing evidence on the impact of regulations on financial reporting quality is mixed. For instance, while Gebhardt and Novotny-Farkas (2011) show that IFRS improves reporting quality of banks, Callao and Jarne (2010) document that IFRS lowers reporting quality of non-financial firms. We make another 
important contribution by providing fresh evidence of the impact of SACORD regulations on EU banks' reporting quality.

We employ a difference-in-differences (DID) estimation approach commonly used for examining the effects of changes in regulation (e.g., Altamuro \& Beatty, 2010; Petacchi, 2015). It is important that the effects associated with SACORD are isolated. For this purpose we exploit the staggered implementation of SACORD for examining the impact on compliance costs, risk taking and the quality of financial reporting of the EU banks. For robustness, we follow an approach similar to the one used by Bargeron et al. (2010) and Dambra et al. (2015) and use the US and Canadian banks as control sample. Importantly, to mitigate the concern that changes in our sample composition might affect our results, we ensure that both treatment and control samples have at least one observation in the pre- and post-SACORD period.

Our results offer a robust evidence of a significant impact of the SACORD regulations on the EU banks. We find that for EU sample only, the compliance costs increase by 11 to 13 percent. The relative increase in the compliance costs is even greater (20 to 26 percent) when we use the control sample of the non-EU banks. Further, relative to the larger banks, smaller banks seem to be disproportionately affected by the increase in compliance costs. Next, postSACORD, we find a significant increase in risk-taking by the EU banks. Evidence suggests that the risk taking is greater for larger banks. Finally, we find that the increased disclosure requirements have a favourable impact on the quality of financial reporting of the EU banks.

The rest of the paper is organised as follows. Section 2 provides a discussion of relevant literature and SACORD provisions which have implications for compliance cost, risk taking and financial reporting. Section 3 explains data and methods used in the study. Section 4 presents and discusses empirical findings. Section 5 concludes the paper. 


\subsection{SACORD and EU Banks}

As mentioned earlier, while SACORD regulations apply to all publicly listed firms in the EU, some of the provisions have greater implications for the banking sector. For instance, Article 3 of the CRD amends the $4^{\text {th }}$ Directive (78/660/EEC) and the Credit Institutions Directive (86/635/EEC) and includes a provision that requires listed banks to include a corporate governance statement in their annual reports. Further, the provision strengthens bank supervision by ensuring financial statements are prepared and published in accordance with the legislation (Article 50b of 78/660/EEC). Article 3 also includes provision for imposition of financial penalties on banks and financial institutions that infringe national provisions (Article 60a of 78/660/EEC). ${ }^{2}$ The Basel Committee on Banking Supervision (BCBS) $(2015$, p.3) notes, "Effective corporate governance is critical to the proper functioning of the banking sector and the economy as a whole". This suggests that sound corporate governance improves the financial stability of banks. Extant literature too has shown that corporate governance does influence quality of financial reporting and risk taking in banks (e.g., DeYoung et al., 2013; Moreno \& Takalo, 2016).

\subsection{SACORD and compliance costs}

Many EU banks expect that increased regulation will significantly increase compliance costs. HSBC's threat to relocate its headquarters to Hong Kong from the UK due to higher

\footnotetext{
${ }^{2}$ During the period 2008-2012, ten banks paid fine of about $£ 150$ billion for various misconducts (McCormick, 2013).
} 
compliance costs is a case in point. ${ }^{3}$ The following provisions of SACORD lead us to predict that these will adversely affect the compliance costs of the EU banks.

Directive 2006/43/EC on statutory audits (SAD) aims to harmonise the quality of audits in the EU, whereas Directive 2006/46/EC on corporate reporting (CRD) aims to promote credible financial reporting processes. The overall objectives of SAD and CRD are to improve corporate governance, transparency and disclosure of accounting information. These regulations aim to promote reliable financial reporting, improve comparability and enhance public confidence in the audit function.

Article 26 of the SAD requires adoption of the International Auditing Standards (IAS) and article 2 of the CRD demands disclosure of Off-Balance Sheet (OBS) arrangements and Related Party Transactions (RPTs). Further, Article 1(7)(2) of CRD requires statutory auditors to verify that annual reports include a corporate governance statement by the board of directors. These measures aim to enhance confidence in the audit quality and the credibility of financial reports. ${ }^{4}$

We argue that the adoption of the IAS will significantly increase auditors' workload and costs. Further, over the years, the use of OBS activities (e.g., standby letters of credit, guarantees, special purpose entities, etc.) in the banking sector has increased significantly (Mills \& Newberry, 2005). Banks were not required to disclose the OBS assets and liabilities in the financial statements prior to the introduction of SACORD. However, post-SACORD, banks will be required to disclose these items in the notes to the annual accounts.

\footnotetext{
${ }^{3}$ See, Arnold et al. (2015)

${ }^{4}$ http://www.kapitalmarktrecht-iminternet.eu/en/Areas\%20of\%20Law/Company_Law/European_Law/96/Directive_2006_46_EG.htm (accessed 02.07.15).
} 
Previous research suggests that RPTs can be used to facilitate personal gains, profit expropriation and fraudulent reporting (e.g., Ryngaert \& Thomas, 2012). According to the American Institute of Certified Public Accountants (2001), these transactions are difficult to identify and auditors have to rely on the management to provide information on RPTs. Lo and Wong (2016) show that adequate disclosure of RPTs can complement weak corporate governance and improve the value relevance of financial statements.

To the extent that the statutory auditors are now required to conduct their audit in accordance with the IAS requirements, and carry out quality assurances on OBS and RPTs, we expect a significant increase in the audit fees. This argument is consistent with previous evidence which suggests that new regulations significantly increase compliance costs (see, for example, Iliev, 2010). Further, since SACORD legislation will significantly increase both the extent and quality of statutory audit work, auditors will charge a higher fee to compensate for the additional work. This will lead to a significant increase in audit costs post-SACORD. Thus our first null hypothesis is:

H10: The compliance costs for the EU banks would not change post-SACORD.

\subsection{SACORD and bank risk taking}

We expect SACORD will affect risk taking because of the following two reasons. First, to ensure the effectiveness of the internal control systems and promote credible financial reporting processes, Article 41(1) of the SAD requires that the audit committee should consist of at least one independent director with financial expertise. Article 41(2b) requires publicinterest entities (PIEs) ${ }^{5}$ to form an audit committee with specific responsibility to monitor the effectiveness of internal control, internal audit, and risk management systems. Article 41(4)

\footnotetext{
${ }^{5}$ Article 2 of the CRD defines public-interest entities (PIEs) as publicly listed companies, credit institutions, insurance entities and any other entities designated by the member states as public-interest entities because they are of significant public interest.
} 
requires the statutory auditor to report to the audit committee any material weaknesses in the internal control systems. Further, Article 1(7) of CRD entails the board to include in the annual financial report, a corporate governance statement that outlines the internal control and risk management systems. Second, greater disclosure requirements in SACORD as discussed above and Article 2 of the CRD regarding disclosure of OBS and RPTs will increase transparency and influence the risk-taking of the EU banks.

The extant literature has found a link between audit and reporting regulations and risk taking. For instance, Sun and Liu (2014) examine the effects of audit committee on bank risktaking and report a negative association between audit committee's effectiveness and risk. Danisman \& Demirel (2019) provide evidence that bank regulations lower risk-taking. Bushman and Williams (2015) argue that publicly disclosed financial reports are a key source of transparency that can help in reducing risk-taking and enhancing financial stability of banks. Consistent with this view, Akhigbe et al. (2016) report a reduction in risk-taking by the US banks after the passage of the Dodd-Frank regulation.

There is, however, a body of research which argues that more regulation can be counterproductive as higher costs of more disclosures can result in increased risk-taking. Hyytinen and Takalo (2002) argue that more transparency can have detrimental effects as it imposes, not only direct compliance costs, but also substantial indirect costs on the banks. For example, information collected by a bank can be seen by competitors, thereby creating a free rider problem leading to reduced profitability. They argue that this worsens the moral hazard problem and reduces the costs of risk taking. Another argument is that bank managers' incentives are linked to market prices, and the banks' cash flows are not necessarily exogenous. Hence, an increase in compliance costs imposed by increased disclosure requirements can lead to sub-optimal behaviour and encourage managers to invest in riskier projects (Goldstein and 
Sapra, 2013). Moreno and Takalo (2016) argue that more transparency can increase depositors' uncertainty about the solvency of banks. Since banks typically finance long term assets through short term borrowings, this increases the probability that the creditors may not roll over the financing creating incentives for increased risk-taking. In a similar vein, Lundtofte and Nielsen (2019) find that banks increase the proportion of high risk-high earnings assets in their portfolio to offset higher costs imposed by stricter regulations.

Given the competing arguments, SACORD's effect on risk taking is not a priori obvious and hence our second null hypothesis is:

H20: Risk-taking by the EU banks will not change post SACORD.

\subsection{SACORD and quality of financial reporting}

It is widely reported that greater disclosures enable investors to more effectively prevent managerial rent extraction, strengthen market discipline, and increase transparency of sensitive financial information. ${ }^{6}$ Prior literature also suggests increased disclosures are associated with improved financial reporting quality. ${ }^{7}$ For instance, Barth et al. (2008) analyse the association of International Accounting Standards (IAS) and accounting quality for 21 countries and demonstrate that the adoption of IAS leads to higher reporting quality. Iatridis (2008, 2010) finds evidence of more relevant accounting quality following IFRS implementation for listed non-financial firms in the UK. Gebhardt and Novotny-Farkas (2011) report a reduction in income smoothing behaviour of the European banks post-IFRS adoption. Further, Altamuro and Beatty (2010) find a positive association between the implementation of the mandated internal control provisions of the Federal Depository Insurance Corporation

\footnotetext{
${ }^{6}$ See Leuz and Wysocki (2016) for a survey of the disclosure literature

${ }^{7}$ Barth and Schipper (2008; p.173) define financial reporting quality as "the extent to which financial reports reveal an entity's underlying economics in a way that is readily understandable by those using the financial reports."
} 
Improvement Act (FDICIA) and higher reporting quality. Papadamou and Tzivinikos (2013) find an association between the implementation of IFRS and improvement in the reporting quality of Greek banks. Chan et al. (2015) show that firms increase their timely loss recognition after the adoption of IFRS in the EU, suggesting improved reporting quality post-IFRS.

Although we expect the adoption of SACORD will improve the reporting quality of the EU banks, Goldstein and Sapra (2013) argue that improved transparency may have negative impact on banks because it can undermine their ability to produce private money and induce managers to make inefficient investment decisions, respectively. Similarly, as argued by Vashishtha (2014), since shareholders are concerned about costs, they may be satisfied with fewer disclosures so that the firm's market value of the assets and revenue are protected from competitors. Further, Thakor (2015) demonstrates that banks may choose to disclose less as more disclosures may increase their fragility. Callao and Jarne (2010) also find evidence of lower reporting quality for non-financial firms post IFRS adoption. As a result, whether regulation improves reporting quality remains an open question. Thus our third and final null hypothesis is:

H30: The quality of financial reporting will not change post SACORD.

\section{SAMPLE SELECTION, METHODS, AND DESCRIPTIVE STATISTICS \\ 3.1 Data and Sample Selection}

We collect data from DataStream using annual financial statements of all listed banks in the EU, US and Canada from 2004 to $2013 .{ }^{8}$ The missing information is extracted from the annual reports from Perfect Filing database. We choose 2004 as the start date because audit fee

\footnotetext{
${ }^{8}$ We use listed banks because audit fees and stock return data for unlisted banks are not available.
} 
data are available only for a small number of the EU banks prior to that. Although our focus is to study the effects of the SACORD on audit costs, we also include non-audit fees since previous research has shown a significant positive association between audit fees and non-audit fees (e.g., Schmidt, 2012).

We classify all observations from 2004 to the year before SACORD adoption as preSACORD and all observations from the year of implementation to 2013 as post-SACORD (see Table 1 for an overview of the sample composition and year of adoption by country). ${ }^{9}$ We end in 2013 because as Bertrand et al. (2004) point out, using a shorter sample period around the event in difference-in-differences mitigates concerns about serial correlation in residuals. For a bank to be included in our sample, we require at least five years of data on key accounting variables. Further, we exclude banks which commenced their operation after 2008 and/or banks for which audit fees is not available. Our final sample comprises 464 listed banks, 137 banks (1,296 bank-years) from the EU and 327 banks (3,227 bank-years) from the US and Canada.

\section{$>$ Insert Table 1 here<}

\subsection{Research Methods}

\subsubsection{Difference-in-differences}

We use the Difference-in-Differences (DID) analysis that is considered most effective for examining the unique effects of regulatory changes (e.g., Chan et al., 2015; Dambra et al., 2015; Petacchi, 2015). The DID estimation combines the difference between the treatment and the control samples and pre-post comparison evaluation methodologies. It assumes that both samples would have followed parallel paths over time if the treatment sample is not affected

\footnotetext{
${ }^{9}$ Although, Norway is not a member of the EU, it has adopted the EU directive(s) in pursuance of access to the European's single market. Therefore, we include Norway in our treatment sample. We exclude Cyprus, Estonia, Latvia, Malta and Romania because of lack of sufficient data.
} 
by a specific intervention and estimates the change in outcome over time in the two samples (Wooldridge, 2012). A key challenge in implementing the DID involves identifying a control sample that is not affected by the regulation (e.g., Leuz \& Wysocki, 2016). We use two different methods to identify the control sample for our DID specification. First, we exploit the different SACORD adoption dates for the countries included in our sample in Table 1 to obtain the differences-in-differences estimates of the effect of the regulation on costs, risk taking and reporting quality. The staggered implementation of the SACORD over time allows us to use the EU banks in the sample as both control and treatment sample. Particularly, banks in any country within the EU that has not adopted the directive are considered as control firms, whereas banks in a country that has adopted the directive are considered as treatment firms. For example, all banks in Italy are control banks until 2010 (see Giroud, 2013; Christensen et al., 2016 for similar empirical identification strategy). Thus, if SACORD is impacting the audit fees, any increase should be concentrated in the EU Banks post SACORD. In Table 1 we provide SACORD adoption dates for different countries included in the sample.

Second, we also use a different control sample comprising the US and Canadian banks for ensuring robustness of our results. There is a general agreement in the extant literature that developed economies like the US, UK and the EU are exposed to similar underlying economics (Gerakos et al., 2013) and financial regulation (Coates \& Srinivasan 2014). These countries also share similar institutional arrangements (La Porta et al., 2006), and have comparable capital market environments and regulations (Bargeron et al., 2010). Previous studies on the U.S. market use European and Canadian firms as control sample. For example, Bargeron et al. (2010), Lee et al. (2014) and Dambra et al. (2015) use firms from the UK, Canada, Germany and France as control sample for investigating the effects of SOX, Regulation Fair Disclosure and the JOBS Act respectively. We follow a similar approach and use listed banks in the US and Canada as the control sample as these are not affected by the SACORD. 
With an aim to ensure that the parallel trends assumption of difference-in-differences estimation is satisfied in the pre-treatment years spanning 2004-2007, we follow Rosenbaum and Rubin (1985), and Barbopoulos et al. (2016) and match our sample variables by year before the implementation of the SACORD. We identify the matched sample through a probit regression using firm size (LnAssets), profitability (ROA), business risks (Nloan/TA), business complexity (LnAccruals/TA), income diversity (NIR/Rev), profitability (ROA), and financial distress (LTDebt/TA, LnSTDCFO). We use the nearest neighbour matching without replacement, employing a caliper distance of 0.03 to avoid bad matches. We analyse the differences in matching covariate balance between the EU and the non-EU banks, by following Focke et al. (2017) and compute the normalized differences in the pre-SACORD periods. ${ }^{10}$

Results (not tabulated here but available on request) show that our matched samples are similar with respect to the treatment variables in both periods on all but one variable. Further, the absolute value of the normalized differences $(\Delta x)$ for all variables in the matched sample is below the 0.25 threshold, indicating that the differences in the covariates between the two groups are not economically significant. Thus, our treatment and control sample are similar in terms of the matched variables. ${ }^{11}$

A possible concern with our DID analysis is the likelihood of endogeneity of the policy measures, which may bias our results. However, the formulation of the directives across the EU member countries to improve corporate governance and financial reporting quality precedes our sample period by several years. Thus, SACORD is not a consequence of the need to improve regulation by any particular country in response to any particular event. It is unlikely that the policymakers would have anticipated the ensuing financial crisis and

\footnotetext{
${ }^{10}$ Imbens and Wooldridge (2009) suggest the computed normalized differences should not exceed 0.25 to remove specification sensitivity in the regression.

${ }^{11}$ The results are not tabulated here but can be made available on request.
} 
introduced the SACORD regulations in 2006 with effective dates from 2008. For these reasons, reverse causality is unlikely to be an issue our analysis (see Christensen et al. 2016 for similar arguments). Further, the member states also have some discretion in the implementation of SACORD provisions.

\subsubsection{The SACORD and the Audit costs}

For testing our first hypothesis, we estimate the following baseline DID model. ${ }^{12}$ The aim is to examine whether the SACORD explains the cross-sectional time series variation in changes in the audit fees:

$$
\begin{aligned}
& \text { Auditfees }_{i t}=\alpha_{t}+\theta_{i}+\beta_{1} \text { PsSACORD }_{t}+\emptyset \text { Controls }_{t}+\varepsilon_{i t} \\
& \text { Auditfees }_{i t}=\alpha_{t}+\theta_{i}+\beta_{1} \text { EUR }_{\text {A }} \text { PSSACORD }_{t}+\emptyset \text { Controls }_{t}+\varepsilon_{i t}
\end{aligned}
$$

In the above linear regressions, we use equation 1(a) for the EU only sample and equation $1(\mathrm{~b})$ is for the matched sample. We use the natural logarithm of audit fees (Auditfees) as a proxy for compliance costs (see De George et al., 2013; Iliev, 2010) partitioned on preSACORD period (2004 to the year prior to the adoption) and post-SACORD period (year of adoption to 2013). $a_{t}$ is year fixed effects, $\theta_{\mathrm{i}}$ is firm fixed effects, $\beta_{1}$ is the coefficient of our primary variable of interest which captures the interaction between the indicator for the EU Banks (EUR=1 if EU Bank) and the SACORD's post-adoption period (PsSACORD=1 if post SACORD). If EU banks experience an increase in audit fees post-SACORD, then the coefficient $\beta_{1}$ that captures the differential changes in audit fees should be positive.

Controls $_{t}$ denotes a vector of control variables included to isolate the effects of the SACORD on the EU banks. To account for any systematic difference in the compliance costs

\footnotetext{
${ }^{12}$ We do not include a dummy variable for the main effect since in the firm fixed effects model, such a dummy would be dropped from the regressions and the fixed effects effectively converts Eq. (1) into a difference-indifferences specification (see, for example, Dambra et al., 2015).
} 
associated with the sample, we control for other company-specific characteristics in our model. Natural logarithm of total assets (LnAssets) is a control for firm size (Iliev, 2010). Loss indicator (Loss_Ind) is a dummy variable that equals one if a firm reports a loss for the year, and Return on assets (ROA) are the profitability control variables (De George et al., 2013). The standard deviation of cash flows from operations (LnSTDCFO) and long-term debt scaled by total assets (LTDebt/TA) are measures of financial distress (Chen et al., 2016a). Accruals (LnAccruals/TA) and number of geographic business operations (LnGeoSegmts) are control variables for business complexity (Iliev, 2010). Additionally, we measure bank risk using net loans to total assets (Nloan/TA) and nonperforming loans to total assets (NPL/TA) (Berger et al., 2016). We include the number of audit committee members (LnAuditCommN) as a control for the board's effective oversight (Badolato et al., 2014). Tobin's q (Tobin's Q) is a measure of firm performance (Badertscher et al., 2014). We include non-interest income scaled by revenue (NIR/Rev) to control for income diversity and higher dependence on off-balance-sheet activities (Ellul \& Yerramilli, 2013). Following Ho et al., (2016), we control for financial crisis (FINCRS) via a dummy which equals one during the period 2007 to 2009, and zero for other non-crisis periods. We control for the effect of Basel II by way of a dummy that equals one from the period countries adopted the BASLE regulation ${ }^{13}$ and for the impact of International Financial Reporting Standards (IFRS) via a dummy that equals one from 2005 for countries which adopted the IFRS. ${ }^{14}$

To account for country specific effects, we include the natural logarithm of real GDP per capita (LnGDPPerCap) obtained from World Development Indicator (WDI). We also

\footnotetext{
${ }^{13}$ See the appendix for details. Also see European Parliament Briefing note on US implementation of Basel II. Available at: http://www.europarl.europa.eu/document/activities/cont/201110/20111012ATT29102/20111012ATT29102EN. pdf (access 17.05.2015)

${ }^{14}$ We do not control for types of audit firms as almost all the EU banks in our sample are audited by the BIG 4.
} 
include Heritage Foundation's economic freedom index (EconFreedm) that comprises various economic development indicators such as government integrity, fiscal health, monetary freedom, investment freedom, etc. to control for institutional factors that might affect the overall level of bank efficiency in a country (Barrell \& Nahhas, 2019). ${ }^{15}$ All variables are defined in the Appendix.

Our DID analysis is robust to firm and year fixed effects that account for any timeinvariant and cross-sectional heterogeneity in audit fees. The estimated standard errors are clustered at the firm level and corrected for heteroscedasticity (Petersen, 2009). ${ }^{16}$

\subsubsection{The SACORD regulation and risk taking}

For testing our second hypothesis, we estimate the regression model as specified in equation (2). We include country fixed effects to capture variation in developmental activities and institutional qualities that have been shown by prior literature to be associated with risk taking across countries over time. We include year fixed effects to control for unobserved time varying global shocks. The standard errors are double-clustered by firm and year to adjust for heteroscedasticity as well as serial- and cross-correlation (e.g., He et al., 2014). Specifically, the regression model is defined as:

$$
\begin{aligned}
& \operatorname{RISK}_{i t}=\alpha_{t}+\theta_{i}+\beta_{1} \text { PSSACORD }_{t}+\gamma X+\varepsilon_{i t} \\
& \text { RISK }_{i t}=\alpha_{t}+\theta_{i}+\beta_{1} \text { EUR } * \text { PSSACORD }_{t}+\gamma X+\varepsilon_{i t}
\end{aligned}
$$

We use equation 2(a) in the above model for the EU only sample and equation 2(b) for the matched sample. RISK in equation (2) is measured using four different proxies for risk taking. First, we use stock return volatility estimated as the natural logarithm of the standard deviation

\footnotetext{
${ }^{15} \mathrm{http}: / / \mathrm{www}$.heritage.org/index/explore

16 The results are robust to clustering standard errors by country.
} 
of daily stock returns in the fiscal year (Goetz et al., 2016). Higher volatility indicates higher risk taking. We exclude the bank-year observations for which we do not have stock price data for more than $30 \%$ in a year.

Second, following Goetz et al. (2016), we compute a Z-score for each bank that is considered a composite risk measure of bank stability.

$Z-$ Score $_{r t n}=\operatorname{Ln}\left(\frac{R O A+C A R}{\sigma(S D S R)}\right)$

where ROA is the return on assets, CAR is the capital asset ratio and $\sigma(S D S R)$ is one year standard deviation of daily stock returns for each bank. The Z-score estimates the number of standard deviations by which profits would have to fall before a bank becomes bankrupt (Roy, 1952).

Third, following Laeven and Levine (2009), we use another version of the Z-score where the dispersion is measured as the standard deviation of return on assets.

$$
Z-\text { Score }_{\text {roa }}=\operatorname{Ln}\left(\frac{R O A+C A R}{\sigma(R O A)}\right)
$$

where ROA is the annual return on assets, CAR is annual equity capital to assets ratio of each bank and $\sigma(R O A)$ is standard deviation of annual values of return on assets calculated over 3year overlapping periods starting from the current period t to $\mathrm{t}-2 .{ }^{17}$ Since the Z-score is highly skewed, we use its natural logarithm (e.g., Laeven \& Levine, 2009; Houston et al. 2010). In our analysis, we multiply it by (-1) to ensure that a higher Z-score reflect higher risk-taking.

Our fourth measure of risk is the Distance to Default (DD) using Merton's (1974) model. ${ }^{18}$ We implement a naive approach of Bharath and Shumway (2008) because they show that their approach is at least as good as more complex approaches (e.g., Vassalou and Xing

\footnotetext{
1721 firm-year observations were less than zero and therefore these were excluded.

${ }^{18}$ We would like to thank the anonymous reviewer for this suggestion.
} 
2004 , Hillegeist et al., 2004). We compute the default probability $\left(\pi_{n a i v e}\right)$ for each bank as follows:

$\pi_{\text {naive }}=\mathcal{N}(-$ naive $D D)$

where

naive $D D=\frac{L n\left[\frac{E+F}{F}\right]+\left(r_{i t-1}-0.5 * \sigma_{V}^{2}\right) * T}{\sigma_{V^{*} \sqrt{T}}}$

$\sigma_{V}=\frac{E}{E+F} \sigma_{E}+\frac{F}{E+F}\left(0.05+0.25 * \sigma_{E}\right)$

and $E$ is the market value of the bank's equity, $F$ is the book value of debt, $r_{i t-1}$ denotes the bank's prior year stock returns, $\sigma_{E}$ is equity volatility measured as the annualised standard deviation of daily returns, $T$ is the time period and set to be one year, $\mathcal{N}($.$) is the cumulative$ normal distribution that converts distances to default into default probabilities, and $\pi_{\text {naive }}$ is the physical probability of default calculated over one year. A positive coefficient indicates higher probability of default suggesting increased bank risk-taking.

The fifth and final measure of risk is the ratio of nonperforming loans to total assets ratio (NPL/TA) (Berger et al., 2016). ${ }^{19} \mathrm{~A}$ high ratio indicates greater risk-taking.

We use deposits scaled by total assets (Deposit/TA) to control for market power (Marrouch \& Turk-Ariss, 2014) and cash flow from operations scaled by total assets (CFO/TA) as proxy for cash holding (Chen et al., 2016b). Further, we include the natural log of the percentage of institutional shareholding (LnInst_Investor) in a firm to control for institutional influence on risk taking. Following Bocola et al. (2019) who argue that public debt to GDP ratio is an appropriate proxy to capture sovereign crisis, we include Debt/GDP to control for

\footnotetext{
${ }^{19}$ Non-performing loans are defined as 90+ days delinquent but not yet included in the Loan Loss Provisions.
} 
European sovereign debt crisis. Other controls remain the same as in equations (1) and (2). All variables are defined in the Appendix.

\subsubsection{SACORD regulation and reporting quality}

For testing our third hypothesis regarding the SACORD's impact on the reporting quality, we use two proxies: predictability of loan charge-off and predictability of cash flows (Altamuro \& Beatty 2010; Lafond \& You 2010). Specifically, we use the following OLS regression models (5a) and (6a) for the EU only sample, and (5b) and (6b) for the matched sample: ${ }^{20}$

Chargeoff $_{t+1}=\alpha_{t}+\beta_{1} P S S A C O R D+\beta_{2} L L P / T A_{t}+\beta_{3} P s S A C O R D * L L P / T A_{t}+N P L /$ $T A_{t}+\operatorname{LnT} A_{t}+\varepsilon_{t}$

Chargeoff $_{t+1}=\alpha_{t}+\beta_{1} P S S A C O R D+\beta_{2} L L P / T A_{t}+\beta_{3} E U R * P S S A C O R D * L L P / T A_{t}+$ $N P L / T A_{t}+\operatorname{LnT} A_{t}+\varepsilon_{t}$

and

$$
\begin{aligned}
& E B P_{t+1}=\alpha_{t}+\beta_{1} P S S A C O R D+\beta_{2} R O A_{t}+\beta_{3} P S S A C O R D * R O A_{t}+\operatorname{LnT} A_{t}+\varepsilon_{t} \\
& E B P_{t+1}=\alpha_{t}+\beta_{1} P S S A C O R D+\beta_{2} R O A_{t}+\beta_{3} E U R * P s S A C O R D * R O A_{t}+\operatorname{LnT} A_{t}+\varepsilon_{t}
\end{aligned}
$$

where Chargeof $_{t+1}$ is the loan charge-offs during year $t+1$ scaled by year $t$ total assets and $E B P_{t+1}$ is the Pre-tax income before provision for loan loss during year $t+1$ scaled by total assets of year $t$. Other variables are as defined in the Appendix. With respect to loan chargeoff model in equation (5), our first measure, the effect of SACORD adoption on bank reporting quality is measured by the coefficient $\left(\beta_{3}\right)$ on the interaction variable

\footnotetext{
${ }^{20}$ Results are robust when clustered at country level.
} 
[EUR*]PsSACORD*LLP/TA. Existing literature (e.g., Kanagaretnam et al., 2004) shows banks can exploit loan loss provisions (LLP) to smooth earnings and hence they are less informative about next-period loan charge-offs. ${ }^{21}$ As Altamuro and Beatty (2010) note, current LLP will be positively related to the future charge-offs if it provides information about future loan defaults and will be negatively related if it is used for income smoothing. Therefore, if the implementation of SACORD improves bank reporting quality through its influence over the informativeness of LLP, we expect a positive relationship between the current LLP and future charge-offs.

Regarding the predictability of cash flows model in equation (6), the coefficient on the [EUR*]PsSACORD*ROA is the primary variable of interest as it captures the ability of current earnings to predict future cash flows. Extant literature posits that accounting regulation is associated with greater predictability of cash flows (e.g., Altamuro \& Beatty, 2010). Thus, if SACORD enhances reporting quality, we expect the coefficient of the interaction term $\left(\beta_{3}\right)$ to be positive.

4

EMPIRICAL ANALYSIS AND RESULTS

\subsection{Descriptive Statistics}

Panel A of Table 2 reports the descriptive statistics for the variables used in our analyses for EU banks. The mean value of audit fees is $€ 5.9$ million, with a standard deviation of $€ 12.4$ million and the mean total audit fee is $€ 7.1$ million. The median values are considerably lower in both cases indicating skewness in the fees. Bank assets also show similar skewness with mean $€ 187$ billion and median $€ 18$ billion. Given the skewness of the fees and size distribution,

\footnotetext{
${ }^{21}$ Ahamed and Mallick (2017) highlights that LLP is very important in the banking literature
} 
we use the natural logarithm of audit fees, total fees and the book value of assets in all our empirical specifications. Average bank earns a positive return on assets of 1.4 percent and 12.0 percent of sample firm-years recorded losses. The mean (median) income diversity (NIR/REV) is 28.5 (27.7) percent, indicating that banks rely more on loans to generate revenue. Further, mean value of NPL/TA and LLP/TA is 2.7 and 5.2 percent, while the median value is 1.2 and 0.4 percent, respectively. Given the skewness of NPL/TA and LLP/TA, we use their natural logarithm in our specifications. The mean (median) annual natural logarithm stock return volatility (LnoStkrtn) is 3.21 (3.26), and the average annual negative natural log of Z-score(rtn) and Z-score(roa) is 6.12 and 3.51 respectively. The mean Z-score (roa) is similar to that reported by Houston et al. (2010) and the range in the Z-scores reflects the cross-sectional variation in the level of bank risk.

Panel B of Table 2 shows the descriptive statistics of the matched sample for the regression variables. It is interesting to note that the mean audit fees (total fees) of $€ 6.5$ (€7.6) million before logarithm transformation for the EU banks is not statistically different from benchmark banks of €7.7 (€8.9) million. Further, the EU banks' mean (median) assets of €212 $(€ 12.5)$ billion, are higher than $€ 186(€ 14.2)$ billion for the non-EU banks, but again, the difference is statistically not significant. Treatment (control) sample performance ratio (Tobin's Q) is significantly higher with mean of 92.6 (90.9) percent, suggesting EU banks performance exceed control sample. Treatment (control) sample audit complexity (LnAccruals/TA) is significantly higher with mean $\log$ of $-4.66(-4.85)$, indicating increased complexity of the audit task and risk. Additionally, treatment sample mean natural logarithm of audit committee members ( $\mathrm{LnAuditCommN}$ ) is 1.33 , relative to the control sample of 1.70 and the difference is significant at the 1 percent level. The average of annual $\log$ of ZScore(rtn) of treatment $(-5.84)$ is significantly higher than the treatment sample $(-6.21)$, indicating that EU banks appear to exhibit lower financial stability. 
Finally, the correlation matrix (results not tabulated here but are available on request) shows that Audit fee is positively correlated (0.82) with firm size and with audit complexity (0.61). This is consistent with previously reported findings which suggest that firm size and audit complexity are the key determinants of audit fee. ${ }^{22}$ As correlations of none of the independent variables are greater than 0.6 , multicollinearity is unlikely to be a problem. ${ }^{23}$

$>$ Insert Table 2 here $<$

\subsection{The effects of SACORD on compliance costs}

Table 3 presents results of the effect of SACORD on compliance costs. The key variable of interest is the interaction between the dummy for the EU banks and post-SACORD adoption period (EUR * PSSACORD). The coefficient captures the effect on audit (or total) fees of the EU banks that are affected by the regulations. In column (1), we present the results of the DID specification for audit fees only for the EU banks. The coefficient of PsSACORD is positive $(\beta=0.12)$ and statistically significant at the 5 percent level $(t=2.13)$. This suggests that SACORD adoption significantly increased the EU banks' audit fees by 12.6 percent. ${ }^{24}$

In column (3), we report parallel results of the effects of the SACORD on audit fees based on the matched sample. The coefficient on the key variable of interest remains positive and statistically significant at the 5 percent level $(\beta=0.19, \mathrm{t}=2.10)$. This suggests that post SACORD, audit fees of the EU banks increased by 20.4 percent. These results provide a strong

\footnotetext{
${ }^{22}$ See Hay et al. (2006) for a survey of the literature on the determinants of audit fees

${ }^{23}$ We calculate the variance inflation factors (unreported) and find the VIF are less than 3 for all the regressions.

${ }^{24}$ Kennedy (1981) suggests the appropriate transformation to get a similar interpretation for dummy variables: $\hat{P}=100 *(\exp \{\hat{c}-0.5 * \hat{V}(\hat{c})\}-1)$ where $\widehat{P}$ is the percentage change in the dependent variable given a change in the dummy variable from zero to one, $\hat{c}$ is the coefficient estimate for the dummy variable, and $\hat{V}(\hat{c})$ is the OLS estimate of the variance of the coefficient. It is the transformed coefficient that is discussed in the text.
} 
evidence of a significant increase in the compliance costs of the EU banks following the adoption of the SACORD.

The results in columns (2) and (4) for the total fees are similar. Column (2) with the EU banks only shows a positive and statistically significant coefficient at the 5 percent level for PsSACORD $(\beta=0.10, t=2.05)$ suggesting that the total fees paid by the EU banks to the auditors increased by 10.6 percent following the implementation of the SACORD regulation. The results for the matched sample in column (4), show that the coefficient (EUR * PsSACORD) is also positive and significant at the 1 percent level $(\beta=0.23, \mathrm{t}=2.62)$. The findings imply 26 percent increase in the fee paid by the EU banks post SACORD.

Overall, the findings suggest that the average increase in compliance costs of the EU Banks without additional control sample is between 11 to 13 percent, and 20 to 26 percent relative to the non-EU banks post SACORD. The results in Table 3 strongly reject our null hypothesis $\mathrm{H} 1_{0}$ of no change in compliance costs post SACORD. This is consistent with the findings reported by previous studies. For example, Iliev (2010) reports an increase in audit fees of between 74 and 87 percent for firms that complied with section 404 of the SarbanesOxley Act (SOX) of 2002. In the same vein, De George et al. (2013) report an increase in audit costs of 23 percent following IFRS adoption in Australia.

Finally, the explanatory power of the model is high with an adjusted R-squared of above 77 percent in all four regressions, suggesting that the model is able to explain the crosssectional variation is audit fees. In addition, our results are generally consistent with regard to significance of the control variables (e.g., Petacchi, 2015). ${ }^{25}$

${ }^{25}$ Our main results are unchanged when we use the natural logarithm of revenue or market capitalization as a proxy for size. We also rerun our analyses by excluding observations with large increases in total assets (in excess of 10 percent) in the year after the SACORD implementation. Our findings reported in Table 3 remain robust. Results are available on request. 
$>$ Insert Table 3 here $<$

\subsection{Specification Tests}

We perform two additional tests. First, the implementation of the SACORD regulation coincides with the global financial crisis and economic recession that ensued. Consequently, to mitigate the possible impact of confounding events on our results, we conduct falsification test by rerunning the analyses with hypothetical implementation years of SACORD adoption. If our earlier reported results are affected by the confounding events and the implementation of the SACORD is not an exogenous event, then the measured effects should remain statistically significant when hypothetical implementation years of SACORD are used (see Petacchi, 2015). Further, to satisfy the parallel trend assumption of difference-in-differences tests, the coefficients of EUR $*$ PsSACORD should be insignificant in the pre-event period (e.g., see Li et al., 2018).

Results reported in Table 4 show that the coefficients of EUR $*$ PsSACORD are insignificant for all years except 2008. ${ }^{26}$ This suggests SACORD is an exogenous event and the parallel trend assumption between the treatment and the control sample underlying our analysis holds. The findings support the validity of the parallel trends assumption underlying our analysis.

\section{$>$ Insert Table $4<$}

\subsection{The effects of SACORD on bank risk-taking}

In this section, we test our second null hypothesis $\mathrm{H} 2_{0}$ regarding the impact of the SACORD on risk-taking. In Panel A of Table 5, we present the findings on risk taking as

\footnotetext{
${ }^{26}$ We skipped 2009 and 2010 because of the staggered adoption by EU member countries.
} 
proxied by the natural logarithm of stock return volatility (LnoStkrtn), LnZ-Score (rtn), LnZScore (roa), probability of default ( $\left.\pi_{\text {naive }}\right)$ and nonperforming loans (NPL/TA). The results show that all specifications lead to similar conclusions. Regardless of the risk proxy we use, the coefficient of the variable of interest (PsSACORD) is positive and statistically significant at the 5 percent level or better. In economic terms, when we use return volatility (LnoStkrtn) as a measure of risk (column 1), banks' reported risk rises by 11 percent $(=1 * 0.364 / 3.21)$ after the adoption of SACORD. Column (2) shows that the adoption of SACORD is associated with an increase in banks risk by 11 percent $(=1 * 0.697 / 6.12)$ when $\mathrm{Z}$-Score(rtn) is used as a measure of risk. $^{27}$ Similarly, in column (5), the economic effect/significance of SACORD on nonperforming loan ratio (NPL/TA) is substantial: the regulatory policy change increases risk taking proxied by the ratio of nonperforming loans by 16 percent $(=1 * 0.443 / 2.73)$.

Panel B of Table 5 presents parallel results for the matched sample. Except for LnNPL/TA, the coefficient of the key variable of interest (EUR*PsSACORD) is positive and statistically significant at the 5 percent level or better for all risk proxies. The SACORD effects are similar to those reported in Panel A. Economically, the findings indicate that the EU banks' risk taking increases by 5 percent and 12 percent respectively when Z-Score(rtn) and ZScore(roa) are used as risk proxies. ${ }^{28,29}$ Overall, our results strongly reject the null hypothesis $\mathrm{H} 22_{0}$ of no change in risk taking by the EU banks post SACORD. Our findings imply that the banks may have taken higher risks to offset the increased regulatory costs and/or increased transparency (Goldstein and Sapra, 2013, Moreno and Takalo, 2016). Alternatively, banks

\footnotetext{
${ }^{27}$ Calculated based on DeYoung and Roland (2001).

${ }^{28} \mathrm{We}$ also test the robustness of bank risk taking by using loan loss provision (LnLLP/TA) as a proxy (e.g., Williams, 2004). In Table 6, where we use it as a proxy for reporting quality, we find evidence consistent with the results reported in table 5 .

${ }^{29}$ As an additional robustness test, we exclude banks of some countries that were severely affected by the Eurozone sovereign debt crisis (Greece, Ireland, Italy, Portugal, and Spain) from our sample following Acharya et al. (2018). Our untabulated results are qualitatively similar to those in Panels A and B.
} 
appear to be riskier since they have had to disclose the Off-Balance Sheet transactions which they were not required to disclose prior to SACORD.

$>$ Insert Table 5 here $<$

\subsection{The effects of SACORD on the reporting quality}

In this section, we examine the effects of SACORD on the reporting quality of the EU banks. Table 6 presents the regression estimates of equations (5) and (6) using future loan charge-offs and cash flows with time and firm-level fixed effects. The results show that the coefficients on [EUR*]PsSACORD*LLP/TA are positive and significantly greater than zero $(\beta=0.02, \mathrm{t}=-2.04)$ and $(\beta=0.31, t=-2.33)$ in columns (1) and (3) respectively. This suggests that in the postSACORD period, banks' loan charge-offs became more responsive to loan loss provisions. Similarly, using future cash flow as dependent variable, the coefficients for the variable of interest ([EUR*]PsSACORD*ROA) in columns (2) and (4) are positive and significant at the 5 percent level. The evidence demonstrates that greater transparency required by SACORD has led to improved bank reporting quality. The coefficients on LLP/TA in column (1) is negative but not significantly different from zero while in column (3), it is significantly negative which suggests that banks with higher loan loss provisions have lower charge offs. The results also show that banks with higher non-performing loans and those with lower profitability have higher charge offs. The findings lead us to reject our null hypothesis $\left(\mathrm{H} 3_{0}\right)$.

\section{$>$ Insert Table 6 here $<$}

\subsection{Size effects of SACORD on the compliance costs, risk taking and reporting quality}

Finally, we examine whether the impact of SACORD is similar or different for large and small banks. We define a bank as large if its total assets are greater than the median value for all firm years. We create two dummy variables, (i) large post-SACORD, which takes the 
value of one if the bank is classified as "large", and zero otherwise; and (ii) small postSACORD, which takes the value of one if it is classified as "small", and zero otherwise. To test whether changes in compliance costs, risk taking and reporting quality after SACORD differs significantly between large and small banks, we use the Wald test.

Panel A of Table 7 reports the p-values corresponding to the differences in the two coefficients on compliance costs. The difference is highly significant at the 1 per cent level for different specifications indicating that the compliance costs of small banks are higher than those of large banks in the post-SACORD period. The results are consistent with empirical evidence in the extant literature regarding the disproportionate impact of compliance costs for smaller firms (e.g., see Iliev, 2010). Panel B provides results on risk taking. The p-values from the Wald test assessing the significance are below 0.05 in all specifications suggesting post SACORD, larger banks' risk taking increases much more than smaller banks (except in column 3 for matched sample). Finally, Panel $\mathrm{C}$ shows the differences in terms of the reporting quality. The results indicate that though the reporting quality improves for both the small and large banks, there is no conclusive evidence of the differential impact on the reporting quality by bank size.

\section{$>$ Insert Table 6 here $<$}

\section{$5 \quad$ CONCLUSIONS}

In the aftermath of the 2007-09 financial crisis, many new financial regulations were created and existing regulations have been revised. The extant research does not offer conclusive evidence of the costs and benefits of regulations and whether more regulations improve transparency and moderate risk taking. Excessive regulations can stifle competition and increase compliance costs which could reduce profits and encourage banks to take greater risks. The EU issued new regulations regarding the conduct of statutory audit and corporate 
reporting standards that require greater oversight by auditors for ensuring improved corporate governance, internal controls and greater disclosures. The paper makes important contributions to the extant literature on the cost implications and effectiveness of regulation in reducing risk and improving quality of financial reporting including risk disclosures. We use a robust analytical approach including a variety of control variables and a control sample of 327 US and Canadian listed banks. Our results show that post SACORD, compliance costs of the EU banks have significantly increased. We also find that the increase in compliance costs is disproportionately higher for the smaller banks.

Next, we investigate how greater risk disclosures required by the SACORD regulations affect risk taking. Counterintuitively, our results indicate that post-SACORD there is a significant rise in risk-taking by the EU banks. Further, the increase in risk taking is greater for larger banks. Our results lend support to the extant literature that greater disclosures incentivise banks to take more risks. An alternatively explanation for our results could be that postSACORD the EU banks appear riskier because they are required to disclose more about their Off-Balance Sheet transactions.

Finally, we examine whether the SACORD regulations improve the quality of financial reporting. Our findings show that though post-SACORD, the reporting quality of the EU banks show improvement, we do not find conclusive evidence of the difference in the quality of reporting between large and small EU banks.

We acknowledge that identifying the impact of financial regulation like the SACORD is empirically challenging. However, in our research design, we consider a number of factors and events which could affect our findings. First, we are confident that the implementation of the SACORD regulation was indeed an exogenous event that affected the EU banks. Second, our analytical approach enables us to isolate the impact of SACORD and ensures the 
confounding events did not influence our findings. Finally, our evidence is robust to an alternative speciation that uses a control sample comprising the US and Canadian banks.

Our findings have several key implications. First, financial regulation imposes additional costs especially on smaller EU banks. Second, increased regulation seems to incentivise more risk taking though this could be because of greater disclosure of riskier assets that previously remained Off Balance Sheet. Finally, the implementation of additional regulation seems to be effective in terms of improving the quality of financial reporting that would enable informed decision making by investors. 


\begin{tabular}{|c|c|}
\hline \multicolumn{2}{|c|}{ Variable definitions } \\
\hline LnAuditCommN & $\begin{array}{l}\text { Natural logarithm of } 1 \text { plus the size of the audit committee (from } \\
\text { BoardEx). }\end{array}$ \\
\hline LnAccruals/TA & $\begin{array}{l}\text { The natural logarithm of the ratio of the absolute value of accruals } \\
\text { (difference between net income before extraordinary items and cash flow } \\
\text { from operations) scaled by ending total assets }\end{array}$ \\
\hline LnAuditfees & $\begin{array}{l}\text { Natural logarithm of total audit and audit-related fees charged by the } \\
\text { external auditor for audit related work. }\end{array}$ \\
\hline Basel II & $\begin{array}{l}\text { Basel II dummy equals } 1 \text { for the EU banks from 2006, for the Canadian } \\
\text { banks, from 2007, and for the US banks, from 2008. (see Aiyar, } \\
\text { Calomiris, and Wieladek 2014). The EU banks adopted Basel II in } 2007 \\
\text { but the transition period started earlier (Aiyar, Calomiris, and Wieladek } \\
\text { 2014). Since Basel II it was not adopted by all US banks and also } \\
\text { difficult to identify which US banks are Basel II compliant, we assume } \\
\text { that all US banks adopted Basel II in } 2008 \text {. }\end{array}$ \\
\hline BizDisclos_Ind & $\begin{array}{l}\text { Natural log of Business extent of disclosure index from World } \\
\text { Development Indicators. }\end{array}$ \\
\hline Chargeoff $_{t+1}$ & Loan charge-offs during year $t+1$ scaled by total assets year $t$ \\
\hline $\mathrm{CFO} / \mathrm{TA}$ & Cash flow from operations scaled by total assets \\
\hline Deposit/TA & Total bank deposits scaled by total assets. \\
\hline $\mathrm{EBP}_{t+1}$ & $\begin{array}{l}\text { Pre-tax income before provision for loan loss during year } t+1 \text { scaled by } \\
\text { total assets of year } t\end{array}$ \\
\hline EconFreedm & Economic freedom index from the Heritage Foundation (EconFreedm) \\
\hline FINCRS & Financial crisis dummy equals 1 between $2007-2009$. \\
\hline LnGeoSegmts & $\begin{array}{l}\text { Natural logarithm of } 1 \text { plus the number of geographic segments from } \\
\text { DataStream. }\end{array}$ \\
\hline IFRS & $\begin{array}{l}\text { International Financial Reporting Standards dummy equals } 1 \text { when IFRS } \\
\text { was implemented in EU in 2005-2013 and 2011-2013 in Canada. }\end{array}$ \\
\hline LnInst_Investor & Natural logarithm of percentage of institutional shareholding. \\
\hline LLP/TA & Loan loss provision scaled by total assets. \\
\hline Loss_Ind & Dummy variable equal 1 if the bank reported a loss in the current year. \\
\hline LTDebt/TA & Leverage ratio, measured as the ratio of long term debts to total assets. \\
\hline NIR/Rev & Non-interest-revenue scaled by total revenue. \\
\hline Nloan/TA & Net loans scaled by Total assets. \\
\hline NPL/TA & Nonperforming loans scaled by Total assets. \\
\hline
\end{tabular}


ROA Return on assets. Ratio of pre-tax income to assets.

LnGDPPerCap Natural logarithm of real gross domestic product (GDP) per capita.

Source: World Development Indicators (WDI) of the World Bank and Eurostat.

LnSTDCFO Natural logarithm of the standard deviation of cash flows from operations scaled by total assets where the standard deviation is calculated using the prior years $t-4$ to $t$ with a minimum of three years.

LnoStkrtn Natural logarithm of the standard deviation of daily stock returns measured over one year.

LnAssets Natural logarithm of total assets measured in millions of Euros

Tobin's Q Tobin's Q is measured as: (Equity market value + Liabilities book value $) /($ Equity book value + Liabilities book value) .

LnTotalfees Natural logarithm of total audit fees, audit related fees and non-audit fees paid to the auditors.

LnZ-score(roa) Natural logarithm of return-on-assets and the ratio of equity over total assets divided by the standard deviation of return on assets calculated over 3-year overlapping periods starting from the current period t to t-2 ((Net income / Assets (book value) + Capital / Assets (book values))/ (Standard deviation of return on assets)

LnZ-score(rtn) Natural logarithm of return-on-assets and the ratio of equity over total assets divided by the standard deviation of daily stock market returns over one year ((Net income / Assets (book value) + Capital / Assets (book values))/ (Standard deviation of daily market returns over one year).

$\pi_{\text {naive }} \quad$ Probability of default using Merton (1974). See section 3 for detail explanation.

Debt/GDP Public debt scaled by gross domestic product (GDP). 


\section{REFERENCES}

Acharya V. \& Ryan, S. (2016). Banks' Financial Reporting and Financial System Stability. Journal of Accounting Research, 54, 277-340.

Acharya, V.A., Eisert, T., Eufinger, C. \& Hirsch, C. (2018). Real Effects of the Sovereign Debt Crisis in Europe: Evidence from Syndicated Loans. The Review of Financial Studies, 31, 2855-2896.

Ahamed, M. \& Mallick, S. (2017). House of restructured assets: How do they affect bank risk in an emerging market? Journal of International Financial Markets, Institutions and Money, 47, 1-14.

Aiyar, S., Calomiris, C., \& Wieladek, T. (2014). Does Macro-Prudential Regulation Leak? Evidence from a UK policy Experiment. Journal of Money, Credit and Banking, 46, 181-214.

Akhigbe A., Martin, A. \& Whyte, A. (2016). Dodd-Frank and risk in the financial services industry. Review of Quantitative Finance and Accounting, 47, 395-415.

Altamuro J. \& Beatty, A. (2010). How does internal control regulation affect financial reporting? Journal of Accounting and Economics, 49, 58-74

American Institute of Certified Public Accountants. (2001). Accounting and Auditing for Related Party Transactions: A Toolkit for Accountants and Auditors. Working paper, American Institute of Certified Public Accountants.

Arnold, M., Oakley, D., \& Hughes, J. (2015). HSBC threatens to move headquarters from UK. Financial Times, (April 24).

Badertscher, B., Jorgensen, B., \& Katz, S. (2014). Public Equity and Audit Pricing in the United States. Journal of Accounting Research, 52, 303-39.

Badolato, P., Donelson, D., \& Ege, M. (2014). Audit committee financial expertise and earnings management: The role of status. Journal of Accounting and Economics, 58, 208-30.

Barakat, A. \& Hussainey, K. (2013). Bank governance, regulation, supervision, and risk reporting: Evidence from operational risk disclosures in European banks. International Review of Financial Analysis, 30, 254-273.

Barbopoudos, L., Molyneux, P. \& Wilson, J. (2016). Earnout financing in the financial services industry. International Review of Financial Analysis, 47, 119-132.

Bargeron, L., Lehn, K., \& Zutter, C. (2010). Sarbanes-Oxley and corporate risk-taking. Journal of Accounting and Economics, 49, 34-52.

Barrell, R. \& Nahhas, A. 2019. The role of lender country factors in cross border bank lending. International Review of Financial Analysis, (https://doi.org/10.1016/j.irfa.2019.01.008. 
Barth, M. E., Landsman, W. R., \& Lang, M. H. (2008). International accounting standards and accounting quality. Journal of Accounting Research, 46, 467-498.

Barth, M., \& Schipper, K. (2008). Financial Reporting Transparency. Journal of Accounting, Auditing and Finance, 23, 173-90.

Basel Committee on Banking Supervision (2015). Guidelines: Corporate governance principles for banks. Banks for International Settlements (July).

Berger A., Imbierowicz, B., \& Rauch, R. (2016). The Roles of Corporate Governance in Bank Failures during the Recent Financial Crisis. Journal of Money, Credit and Banking, 48, 729-770.

Bertrand, M., Duflo, E. \& Mullainathan, S. (2004). How Much Should We Trust Differencesin Differences Estimates? The Quarterly Journal of Economics, 119, 249-275.

Bharath, S. \& Shumway, T. (2008). Forecasting Default with the Merton Distance to Default Model. The Review of Financial Studies, 21, 1339-1369.

Bocola, L., Bornstein, G. \& Dovis, A. (2019). Quantitative sovereign default models and the European debt crisis. Journal of International Economics, 118, 20-30.

Bushman, R., Williams, C. (2012). Accounting discretion, loan loss provisioning, and discipline of banks' risk-taking. Journal of Accounting and Economics, 54, 1-18.

Bushman, R., Williams, C. (2015). Delayed Expected Loss Recognition and the Risk Profile of Banks. Journal of Accounting Research, 53, 511-53.

Callao, S., \& Jarne, J. (2010). Have IFRS affected earnings management in the European Union? Accounting in Europe, 7, 159-189.

Chan, A., Hsu, A. \& Lee, E. (2015). Mandatory adoption of IFRS and timely loss recognition across Europe: The effect of corporate finance incentives. International Review of Financial Analysis, 38, 70-82.

Chen P., He, S., Ma, Z., \& Stice, D. (2016a). The information role of audit opinions in debt contracting. Journal of Accounting and Economics, 61, 121-144.

Chen Z., Li, Z., \& Zou, H. (2016b). Directors' and officers' liability insurance and the cost of equity. Journal of Accounting and Economics, 61, 100-120.

Christensen H., Hail, L., \& Leuz, C. (2016). Capital-Market Effects of Securities Regulation: Prior Conditions, Implementation, and Enforcement. Review of Financial Studies, 29, 2885-2924.

Coates J., \& Srinivasan, S. (2014). SOX after ten years: a multidisciplinary review. Accounting Horizons, 28, 627-71.

Cordella, T., Yeyati, E.L. (1998). Public Disclosure and Bank Failures. Staff Papers, International Monetary Fund, 45, 110-131. 
Dambra M., Field, L., \& Gustafson, M. (2015). The JOBS Act and IPO volume: Evidence that disclosure costs affect the IPO decision. Journal of Financial Economics, 116, $121-143$.

Danisman, G. \& Demirel, P. (2019). Bank risk-taking in developed countries: The influence of market power and bank regulations. Journal of International Financial Markets, Institutions and Money, 59, 202-217.

De George, E., Ferguson, C. \& Spear, N. (2013). How Much Does IFRS Cost? IFRS Adoption and Audit Fees. The Accounting Review, 88, 429-62.

DeYoung, R., \& Roland, K. (2001). Product Mix and Earnings Volatility at Commercial Banks: Evidence from a Degree of Total Leverage Model. Journal of Financial Intermediation, 10, 54-84.

DeYoung, R., Peng, E., \& Yan, M. (2013). Executive Compensation and Business Policy Choices at US Commercial Banks. Journal of Financial and Quantitative Analysis, 48, 165-96.

Ellul, A., \& Yerramilli, V. (2013). Stronger Risk Controls, Lower Risk: Evidence from U.S. Bank Holding Companies. The Journal of Finance, 68, 1757-803.

European Banking Federation Report (2018). Banking in Europe: EBF, Facts and Figures 2018, https://www.ebf.eu/wp-content/uploads/2018/09/Banking-in-Europe-2018-EBFFacts-and-Figures.pdf

Flannery, M., Kwan, S. \& Nimalendran, M. (2013). The 2007-2009 Financial crisis and bank opaqueness. Journal of Financial Intermediation, 22, 55-84.

Focke, F., Maug, E., \& Niessen-Ruenzi, A. (2017). The impact of firm prestige on executive compensation. Journal of Financial Economics, 123, 313-36.

Frame, S. \& White, L. (2007). Charter Value, Risk-Taking Incentives, and Emerging Competition for Fannie Mae and Freddie Mac. Journal of Money, Credit and Banking, 39, 83-103.

Gebhardt, G., \& Novotny-Farkas, Z. (2011). Mandatory IFRS Adoption and Accounting Quality of European Banks. Journal of Business Finance and Accounting, 38, 289-333.

Gerakos, J., Lang, M., \& Maffett, M. (2013). Post-listing performance and private sector regulation: The experience of London's Alternative Investment Market. Journal of Accounting and Economics, 56, 189-215.

Giroud, X. (2013). Proximity and Investment: Evidence from Plant-Level Data. Quarterly Journal of Economics, 128, 861-915.

Goetz, M., Laeven, L., \& Levine, R. (2016). Does the geographic expansion of banks reduce risk? Journal of Financial Economics, 120, 346-62. 
Goldstein I. \& Sapra, H. (2013). Should Banks' Stress Tests Results be Disclosed? An Analysis of the Costs and Benefits. Foundations and Trends in Finance, 8, 1-54.

Hay, D., Knechel, R., \& Wong, N. (2006). Audit fees: A meta-analysis of the effect of supply and demand attributes. Contemporary Accounting Research, 23, 141-91.

He, Y., Nielsson, U., Guo, H. \& Yang, J. (2014). Subscribing to transparency. Journal of Banking and Finance, 44, 189-206.

Hillegeist, S. A., Keating, E. K., Cram, D. P. \& Lundstedt, K. G. (2004). Assessing the Probability of Bankruptcy, Review of Accounting Studies, 9, 5-34.

Ho, P., Huang, C., Lin, C., \& Yen, J. (2016). CEO Overconfidence and Financial Crisis: Evidence from Bank Lending and Leverage. Journal of Financial Economics, 120, 194-209.

Houston, J., Lin, C., Lin, P., \& Mae, Y. (2010). Creditor rights, information sharing, and bank risk taking. Journal of Financial Economics, 96, 485-512.

Hyytinen, A. Takalo, T. (2002). Enhancing Bank Transparency: A Re-Assessment. European Finance Review, 6, 429-445.

Iatridis, G. (2008). Accounting disclosure and firms' financial attributes: Evidence from the UK stock market. International Review of Financial Analysis, 17, 219-241.

Iatridis, G. (2010). International financial reporting standards and the quality of financial statement information. International Review of Financial Analysis, 19, 193-204.

Iliev, P. (2010). The Effect of SOX Section 404: Costs, Earnings Quality, and Stock Prices. The Journal of Finance, 65, 1163-1196.

Imbens, G. \& Wooldridge, J. (2009). Recent Developments in the Econometrics of Program Evaluation. Journal of Economic Literature, 47, 5-86.

Kanagaretnam, K., Lobo, G., \& Yang, D. (2004). Joint tests of signalling and income smoothing through bank loan loss provisions. Contemporary Accounting Research, 21, 843-844.

Kennedy, P. (1981). Estimation with Correctly Interpreted Dummy Variables in Semilogarithmic Equations. American Economic Review, 71, 801.

Klomp J., and Haan, J. (2012). Banking Risk and Regulation: Does one Size Fit All? Journal of Banking and Finance, 36, 3197-212.

Koh, K., \& Tong, Y. (2013). The effects of clients' controversial activities on audit pricing. Auditing: A Journal of Practice and Theory, 32, 67-96.

La Porta, R., Lopez-De-Silanes, F., \& Shleifer, A. (2006). What Works in Securities Laws? The Journal of Finance, 61, 1-32.

Laeven, L., \& Levine, R. (2009). Bank governance, regulation and risk taking. Journal of Financial Economics, 93, 259-75. 
LaFond, R. \& You, H. (2010). The Federal Deposit Insurance Corporation Improvement Act, Bank Internal Controls and Financial Reporting Quality. Journal of Accounting and Economics, 49, 75-83.

Lane, P. (2012). The European Sovereign Debt Crisis. Journal of Economic Perspectives, 26, 49-68.

Lee E., Strong, N., \& Zhu, Z. (2014). Did Regulation Fair Disclosure, SOX, and Other Analyst Regulations Reduce Security Mispricing? Journal of Accounting Research, 52, 733-74.

Lehmann, A. \& Nyberg, L. (2014). Europe's Banking Union in the global financial system: Constructing open and inclusive institutions. Working Paper 175, European Bank for Reconstruction and Development.

Leuz, C., \& Verrecchia, R. (2000). The Economic Consequences of Increased Disclosure. Journal of Accounting Research, 38, 91-124.

Leuz, C., \& Wysocki, P. (2016). The Economics of Disclosure and Financial Reporting Regulation: Evidence and Suggestions for Future Research. Journal of Accounting Research, 54, 525-622.

Li, Y., Lin, Y., \& Zhang, L. (2018). Trade Secrets Law and Corporate Disclosure: Causal Evidence on the Proprietary Cost Hypothesis. Journal of Accounting Research, 56, 265-308.

Lo, A., and Wong, R. (2016). Silence Is Golden? Evidence from Disclosing Related-Party Transactions in China. Journal of Accounting and Public Policy, 35, 540-564.

Lundtofte, F. \& Nielsen, C. (2019). The effect of stricter capital regulation on banks' risktaking: Theory and evidence. European Financial Management. (Forthcoming)

Mariathasan M., \& Merrouche, O. (2014). The manipulation of Basel risk-weights. Journal of Financial Intermediation, 23, 300-21.

Marrouch, W., \& Turk-Ariss, R. (2014). Joint market power in banking: Evidence from developing countries. Journal of International Financial Markets, Institutions and Money, 31, 253-267.

McCormick, R. (2013). £150 Billion in Five Years - New League Table Throws New Light on Cost of Banking Misconduct. The London School of Economics and Political Science.

Merton, R. C. (1974). On the Pricing of Corporate Debt: The Risk Structure of Interest Rates. Journal of Finance, 29, 449-470.

Mills, F. L., \& Newberry, K. (2005). Firms' Off-Balance Sheet and Hybrid Debt Financing: Evidence from Their Book-Tax Reporting Differences. Journal of Accounting Research, 43, 251-82. 
Mohsni, S. \& Otchere, I. (2018). Does regulatory regime matter for bank risk taking? A comparative analysis of US and Canada. Journal of International Financial Markets, Institutions and Money, 53, 1-16.

Moreno D., \& Takalo, T. (2016). Optimal Bank Transparency. Journal of Money, Credit and Banking, 48, 203-31.

Papadamou, S. \& Tzivinikos, T. (2013). The risk relevance of International Financial Reporting Standards: Evidence from Greek banks. International Review of Financial Analysis, 27, 43-54.

Pasiouras, F., Tanna, S. \& Zopounidis, C. (2009). The impact of banking regulations on banks' cost and profit efficiency: Cross-country evidence. International Review of Financial Analysis, 18, 294-302.

Petacchi, R. (2015). Information Asymmetry and Capital Structure: Evidence from Regulation FD. Journal of Accounting and Economics, 59, 143-62.

Petersen, M. (2009). Estimating Standard Errors in Finance Panel Data Sets: Comparing Approaches. Review of Financial Studies, 22, 435-80.

Rosenbaum P. \& Rubin, D. (1985). Constructing a control group using multivariate matched sampling methods that incorporate the propensity score. The American Statistician, 39, 33-8.

Roy, A.D. (1952). Safety first and the holding of assets. Econometrica, 20, 431-449.

Ryngaert M., \& Thomas, S. (2012). Not All Related Party Transactions (RPTs). Are the same: Ex Ante Versus Ex Post RPTs. Journal of Accounting Research, 50, 845-82.

Schmidt, J. (2012). Perceived Auditor Independence and Audit Litigation: The Role of Nonaudit Services Fees. The Accounting Review, 87, 1033-065.

Sun J. \& Liu, G. (2014). Audit Committees' Oversight of Bank Risk-Taking. Journal of Banking and Finance, 40, 376-87.

Thakor, A. (2015). Strategic Information Disclosure when there is Fundamental Disagreement. Journal of Financial Intermediation, 24, 131-53.

Vashishtha, R. (2014). The role of bank monitoring in borrowers' discretionary disclosure: Evidence from covenant violations. Journal of Accounting and Economics, 57, 176-95.

Vassalou, M. \& Xing, Y. (2004). Default Risk in Equity Returns. Journal of Finance, 59, 831-868.

Williams, J. (2004). Determining Management Behaviour in European Banking. Journal of Banking and Finance, 28, 2427-460.

Wooldridge, J. (2012). Introductory Econometrics: A Modern Approach. Mason, $\mathrm{OH}$ : Cengage Learning Custom Publishing. 
TABLE 1 Sample distribution and entry-into-force dates

\begin{tabular}{|c|c|c|c|}
\hline Country & $\begin{array}{l}\text { Unique } \\
\text { firms }\end{array}$ & $\begin{array}{c}\text { Observations } \\
(\mathrm{N})\end{array}$ & $\begin{array}{l}\text { Entry-into-force } \\
\text { dates }\end{array}$ \\
\hline Austria & 2 & 20 & August, 2008 \\
\hline Belgium & 2 & 20 & Sept, 2008 \\
\hline Bulgaria & 1 & 9 & Sept, 2008 \\
\hline Czech republic & 1 & 10 & April, 2009 \\
\hline Denmark & 18 & 151 & Sept, 2008 \\
\hline Finland & 2 & 20 & Sept, 2008 \\
\hline France & 21 & 205 & Sept, 2008 \\
\hline Germany & 5 & 50 & April, 2009 \\
\hline Greece & 1 & 10 & April, 2009 \\
\hline Hungary & 1 & 10 & Sept, 2008 \\
\hline Ireland & 2 & 20 & August, 2010 \\
\hline Italy & 20 & 193 & March, 2010 \\
\hline Lithuania & 1 & 8 & Sept, 2008 \\
\hline Luxembourg & 1 & 10 & Sept, 2008 \\
\hline Netherlands & 3 & 29 & Sept, 2008 \\
\hline Norway & 11 & 110 & April, 2009 \\
\hline Poland & 7 & 70 & April, 2009 \\
\hline Portugal & 4 & 36 & Sept, 2008 \\
\hline Slovakia & 1 & 10 & Sept, 2008 \\
\hline Slovenia & 1 & 9 & Sept, 2008 \\
\hline Spain & 9 & 86 & August, 2010 \\
\hline Sweden & 4 & 40 & April, 2009 \\
\hline United kingdom & 19 & 171 & Sept, 2008 \\
\hline \multicolumn{4}{|l|}{ Control sample } \\
\hline Canada & 9 & 90 & N/A \\
\hline United States & 318 & 3,137 & N/A \\
\hline \multicolumn{4}{|c|}{$\begin{array}{l}\text { NOTES: The sample consists of all countries in the European Union except } \\
\text { for Cyprus, Estonia, Latvia, Malta and Romania because of lack of sufficient } \\
\text { data. We also include Norway from the European Economic Area (EEA) as } \\
\text { explained in the text. The control samples are banks from the US and } \\
\text { Canada. }\end{array}$} \\
\hline
\end{tabular}




\begin{tabular}{|c|c|c|c|c|c|c|}
\hline \multicolumn{7}{|c|}{ TABLE 2 (PANEL A) Summary statistics of EU banks } \\
\hline Variable & $\mathbf{N}$ & Q1 & Mean & Median & Q3 & Std. Dev. \\
\hline A AuditFees (€’000) & $1,1,212$ & 222 & 5,885 & 659 & 4,980 & 12,385 \\
\hline TtlAuditfees (€’000) & 1,212 & 234 & 7,080 & 875 & 5,950 & 14,724 \\
\hline Total Assets (€’Mill) & 1,296 & 4,458 & 187,000 & 17,900 & 132,000 & 408,000 \\
\hline Loss_Ind & 1,290 & 0.00 & 0.12 & 0.00 & 0.00 & 0.32 \\
\hline LnGeoSegmts & 1,290 & 0.69 & 1.05 & 0.69 & 1.39 & 0.55 \\
\hline LTDebt/TA & 1,290 & 7.49 & 19.44 & 17.32 & 27.66 & 15.42 \\
\hline NLoan/TA & 1,290 & 60.72 & 68.88 & 72.11 & 83.26 & 18.50 \\
\hline ROA & 1,255 & 0.80 & 1.39 & 1.24 & 1.68 & 1.96 \\
\hline Tobin's Q & 1,265 & 89.52 & 91.22 & 92.86 & 94.78 & 8.08 \\
\hline NIR/Rev & 1,242 & 20.48 & 28.51 & 27.65 & 34.40 & 15.26 \\
\hline LnSTDCFO & 1,217 & -1.43 & -0.78 & -0.92 & -0.23 & 0.96 \\
\hline LnAccruals/TA & 1,290 & -5.36 & -4.67 & -4.62 & -3.94 & 1.27 \\
\hline LnAuditCommN & 1,284 & 1.10 & 1.33 & 1.39 & 1.79 & 1.05 \\
\hline LnGDPPerCap & 1,296 & 10.48 & 10.58 & 10.63 & 10.82 & 0.49 \\
\hline EconFreedm & 1,296 & 1.06 & 1.35 & 1.31 & 1.67 & 0.37 \\
\hline Debt/GDP & 1,296 & 41.75 & 65.29 & 63.74 & 85.31 & 28.48 \\
\hline LnбStkrtn & 1,270 & -3.61 & -3.21 & -3.26 & -2.86 & 0.59 \\
\hline LnZ-score(rtn) & 1,268 & 7.18 & 6.12 & 6.06 & 5.00 & 1.93 \\
\hline LnZ-score(roa) & 1,270 & 4.13 & 3.51 & 3.34 & 2.70 & 1.34 \\
\hline NPL/TA & 996 & 0.45 & 2.73 & 1.23 & 3.43 & 3.99 \\
\hline LLP/TA & 1,166 & 0.17 & 5.22 & 0.40 & 1.06 & 48.09 \\
\hline $\mathrm{CFO} / \mathrm{TA}$ & 1,290 & 0.70 & 1.16 & 1.10 & 1.64 & 2.34 \\
\hline Deposit/TA & 1,247 & 33.06 & 45.27 & 45.43 & 56.02 & 17.96 \\
\hline LnInst_Investor & 1,277 & 0.00 & 2.33 & 2.94 & 3.97 & 1.80 \\
\hline$\pi_{\text {naive }}$ & 1,254 & 0.00 & 24.07 & 0.00 & 41.99 & 39.85 \\
\hline
\end{tabular}


TABLE 2 (PANEL B) Summary statistics of treatment and control groups (matched sample)

\begin{tabular}{|c|c|c|c|c|c|c|c|c|c|c|c|c|c|}
\hline & \multicolumn{5}{|c|}{ Treatment } & \multicolumn{8}{|c|}{ Control } \\
\hline & $\mathbf{N}$ & Q1 & Mean & Median & Q3 & $\begin{array}{r}\text { Std. } \\
\text { Dev. }\end{array}$ & $\mathbf{N}$ & Q1 & Mean & Median & Q3 & $\begin{array}{r}\text { Std. } \\
\text { Dev. }\end{array}$ & $\begin{array}{r}\text { Diff. in } \\
\text { Mean } \\
\end{array}$ \\
\hline AuditFees (€’000) & 354 & 181 & 6,468 & 504 & 5,492 & 13,670 & 358 & 458 & 7,650 & 1,422 & 6,301 & 15,292 & $-1,182$ \\
\hline TtlAuditfees ( $\left.€^{\prime} 000\right)$ & 354 & 210 & 7,593 & 553 & 6,479 & 15,849 & 358 & 458 & 8,876 & 1,470 & 7,751 & 17,431 & $-1,282$ \\
\hline Total Assets (€’Mill) & 366 & 2,826 & 212,000 & 12,500 & 83,000 & 493,000 & 366 & 2,554 & 186,000 & 14,200 & 133,000 & 389,000 & 26,000 \\
\hline Loss_Ind & 366 & 0.00 & 0.12 & 0.00 & 0.00 & 0.32 & 366 & 0.00 & 0.16 & 0.00 & 0.00 & 0.37 & $-0.04 *$ \\
\hline LnGeoSegmts & 366 & 0.69 & 1.08 & 0.69 & 1.39 & 0.55 & 366 & 0.69 & 0.81 & 0.69 & 0.69 & 0.31 & 0.27 \\
\hline LTDebt/TA & 366 & 5.23 & 11.80 & 9.74 & 17.66 & 8.78 & 366 & 5.83 & 12.54 & 10.48 & 15.98 & 11.99 & -0.74 \\
\hline NLoan/TA & 366 & 53.78 & 64.95 & 67.79 & 80.30 & 18.81 & 366 & 57.73 & 64.25 & 66.96 & 73.65 & 14.30 & 0.70 \\
\hline ROA & 366 & 0.76 & 1.33 & 1.26 & 1.87 & 1.02 & 366 & 1.07 & 1.34 & 1.44 & 1.94 & 2.57 & 0.01 \\
\hline Tobin's Q & 366 & 90.86 & 92.55 & 93.09 & 94.88 & 3.36 & 366 & 88.75 & 90.93 & 90.61 & 92.70 & 4.24 & $1.62 * * *$ \\
\hline Debt/GDP & 366 & 40.20 & 59.38 & 48.50 & 80.82 & 25.98 & 366 & 62.22 & 79.75 & 81.12 & 98.70 & 18.37 & $-15.37 * * *$ \\
\hline NIR/Rev & 366 & 0.19 & 0.27 & 0.26 & 0.34 & 0.13 & 366 & 0.14 & 0.26 & 0.27 & 0.36 & 0.15 & 0.01 \\
\hline LnSTDCFO & 366 & -1.39 & -0.89 & -0.98 & -0.33 & 0.78 & 366 & -1.47 & -0.84 & -0.92 & -0.33 & 0.94 & -0.05 \\
\hline LnAccruals & 366 & -5.25 & -4.66 & -4.62 & -3.96 & 1.20 & 366 & -5.43 & -4.85 & -4.66 & -3.79 & 1.45 & $0.19 *$ \\
\hline LnAuditCommN & 363 & 0.69 & 1.33 & 1.39 & 1.61 & 1.21 & 361 & 1.61 & 1.70 & 1.79 & 1.79 & 0.27 & $-0.37 * * *$ \\
\hline NPL/TA & 366 & 0.41 & 1.65 & 0.88 & 2.10 & 1.99 & 366 & 0.35 & 1.82 & 0.97 & 2.33 & 2.38 & -0.18 \\
\hline LnGDPPerCap & 366 & 10.51 & 10.62 & 10.66 & 10.97 & 0.54 & 366 & 10.78 & 10.80 & 10.80 & 10.81 & 0.02 & $-0.17 * * *$ \\
\hline EconFreedm & 366 & 1.09 & 1.43 & 1.51 & 1.77 & 0.37 & 366 & 1.40 & 1.48 & 1.50 & 1.59 & 0.13 & $-0.05 * * *$ \\
\hline LnбStkrtn & 365 & -3.55 & -3.17 & -3.24 & -2.82 & 0.53 & 366 & -3.11 & -3.27 & -2.73 & 0.67 & 365 & -0.1 \\
\hline LnZ-score(rtn) & 365 & -6.84 & -5.84 & -5.87 & -4.87 & 1.60 & 366 & -7.45 & -6.21 & -6.43 & -5.23 & 1.88 & $0.37 * * *$ \\
\hline LnZ-score(roa) & 366 & -3.82 & -3.34 & -3.24 & -2.74 & 1.06 & 366 & -4.34 & -3.58 & -3.43 & -2.80 & 1.48 & $0.24 * *$ \\
\hline NPL/TA & 366 & 0.41 & 1.65 & 0.88 & 2.10 & 1.99 & 366 & 0.35 & 1.82 & 0.97 & 2.33 & 2.38 & -0.18 \\
\hline LLP/TA & 366 & 0.17 & 6.43 & 0.48 & 2.17 & 52.88 & 366 & 0.18 & 0.95 & 0.41 & 1.24 & 1.30 & $5.48 * *$ \\
\hline CFO/TA & 366 & 0.70 & 1.17 & 1.14 & 1.61 & 0.93 & 366 & 1.05 & 1.38 & 1.38 & 1.88 & 0.94 & -0.21 \\
\hline Deposit/TA & 366 & 38.89 & 50.11 & 50.79 & 63.06 & 17.64 & 364 & 60.46 & 66.82 & 68.02 & 74.54 & 11.34 & $-16.71 * * *$ \\
\hline LnInst_Investor & 364 & 0.00 & 2.47 & 2.94 & 4.06 & 1.74 & 363 & 0.00 & 2.11 & 2.48 & 3.22 & 1.42 & $0.36^{* * *}$ \\
\hline$\pi_{\text {naive }}$ & 364 & 0.00 & 23.00 & 0.00 & 30.19 & 39.48 & 366 & 0.00 & 14.52 & 0.00 & 0.00 & 0.05 & $8.49 * * *$ \\
\hline
\end{tabular}




\begin{tabular}{|c|c|c|c|c|c|c|c|c|}
\hline \multirow{4}{*}{ Columns } & \multicolumn{4}{|c|}{ EU banks only } & \multicolumn{4}{|c|}{ Matched Sample } \\
\hline & \multirow{2}{*}{\multicolumn{2}{|c|}{$\begin{array}{c}\text { LnAuditfees } \\
\text { (1) }\end{array}$}} & \multirow{2}{*}{\multicolumn{2}{|c|}{$\begin{array}{c}\text { LnTotalfees } \\
\text { (2) }\end{array}$}} & \multirow{2}{*}{\multicolumn{2}{|c|}{$\begin{array}{c}\text { LnAuditfees } \\
\text { (3) }\end{array}$}} & \multirow{2}{*}{\multicolumn{2}{|c|}{$\begin{array}{c}\text { LnTotalfees } \\
\mathbf{( 4 )}\end{array}$}} \\
\hline & & & & & & & & \\
\hline & Coeff. & t-stat & Coeff. & t-stat & Coeff. & t-stat & Coeff. & t-stat \\
\hline [EUR*]PsSACORD & $0.120 * *$ & 2.13 & $0.102 * *$ & 2.05 & $0.190 * *$ & 2.10 & $0.233 * * *$ & 2.62 \\
\hline IFRS & 0.083 & 1.11 & 0.035 & 0.49 & 0.047 & 0.68 & 0.050 & 0.75 \\
\hline FINCRS & $0.069 * *$ & 2.26 & $0.079 * * *$ & 2.62 & $0.082 * *$ & 2.20 & $0.061 *$ & 1.77 \\
\hline Basel II & $0.116 * *$ & 2.05 & 0.079 & 1.36 & 0.020 & 0.37 & -0.026 & -0.54 \\
\hline LnGeoSegmts & 0.206 & 1.61 & $0.280 * *$ & 2.41 & $0.454 * * *$ & 3.78 & $0.518 * * *$ & 4.17 \\
\hline Loss_Ind & 0.059 & 0.90 & 0.059 & 0.90 & 0.003 & 0.05 & 0.020 & 0.34 \\
\hline LnAssets & $0.503 * * *$ & 4.25 & $0.655 * * *$ & 5.84 & $0.537 * * *$ & 5.51 & $0.507 * * *$ & 4.99 \\
\hline LTDebt/TA & 0.001 & 0.22 & -0.001 & -0.36 & -0.006 & -1.55 & -0.005 & -1.34 \\
\hline NLoan/TA & 0.003 & 0.98 & 0.005 & 1.43 & $0.007 *$ & 1.96 & $0.007 * *$ & 2.16 \\
\hline LnGDPPerCap & -0.546 & -0.71 & -0.509 & -0.67 & 1.138 & 1.19 & 1.247 & 1.30 \\
\hline EcoFreedm & 0.002 & 0.19 & 0.003 & 0.27 & -0.013 & -1.23 & -0.011 & -0.97 \\
\hline Tobin’s Q & $0.038^{*}$ & 1.73 & $0.041 *$ & 1.81 & 0.017 & 1.01 & 0.020 & 1.18 \\
\hline ROA & $0.051 *$ & 1.64 & $0.076 * *$ & 2.55 & -0.013 & -0.44 & 0.000 & -0.01 \\
\hline LnSTDCFO & 0.010 & 0.31 & 0.014 & 0.39 & -0.001 & -0.02 & -0.011 & -0.32 \\
\hline NPL/TA & 0.003 & 0.30 & 0.008 & 0.84 & $0.063 * * *$ & 3.18 & $0.062 * * *$ & 3.14 \\
\hline NIR/Rev & $0.557 * *$ & 2.08 & $0.590 * *$ & 2.27 & $1.029 * * *$ & 2.82 & $0.953 * * *$ & 2.70 \\
\hline LnAuditCommN & $0.116^{* *}$ & 2.26 & $0.082 * *$ & 2.18 & 0.003 & 0.05 & 0.002 & 0.04 \\
\hline LnAccruals/TA & 0.008 & 0.73 & 0.002 & 0.15 & -0.005 & -0.44 & -0.009 & -0.81 \\
\hline Intercept & -0.529 & -0.06 & -3.864 & -0.47 & -15.958 & -1.61 & $-17.073 *$ & -1.70 \\
\hline Impact $(\%)$ & 12.60 & & 10.62 & & 20.41 & & 25.73 & \\
\hline Number of observations & 921 & & 921 & & 706 & & 706 & \\
\hline Adj. R-squared (\%) & 77.41 & & 80.22 & & 78.92 & & 78.45 & \\
\hline Firm fixed effects & YES & & YES & & YES & & YES & \\
\hline Year fixed effects & YES & & YES & & YES & & YES & \\
\hline \multicolumn{9}{|c|}{$\begin{array}{l}\text { NOTES: This table presents the effect of SACORD on audit fees and total fees. The dependent variables are } \\
\text { the Natural logarithm of audit fees and total Fees. In estimating (1) to (4), EUR*PsSACORD is an interaction } \\
\text { dummy variable equals to one if the bank is EU and the period is from the adoption year to } 2013 \text {. We include } \\
\text { year and firm fixed effects to control for any fundamental differences in the fees across years and firms. } \\
\text { Implied fee increase refers to the effect of implementing SACORD regulation on mean banks in EU in } € \\
\text { thousands. Matched sample analysis is based on size (LnAssets), profitability (ROA), financial distress } \\
\text { (LnSTDCFO, LTDebt/TA), business complexity (LnAccruals/TA), income diversity (NIR/Rev) and business } \\
\text { risk (Nloans/TA, NPL/TA). All other firm characteristics are as defined in the Appendix. All continuous } \\
\text { variables are winsorized at the 1st and 99th percentile. Country and year fixed effects are included in each } \\
\text { regression but not reported. The models are estimated by difference-in-differences with standard errors that are } \\
\text { robust to heteroscedasticity and clustered at the firm level. Statistical significance denoted as } * * *, * * \text {, and * for } \\
1 \%, 5 \% \text { and } 10 \% \text { respectively (using a two-sided test). }\end{array}$} \\
\hline
\end{tabular}




\begin{tabular}{|c|c|c|c|c|c|c|}
\hline & \multicolumn{2}{|c|}{ Full Sample } & \multicolumn{2}{|c|}{ Matched Sample } & \multicolumn{2}{|c|}{ EU banks only } \\
\hline & LnAuditfees & LnTotalfees & LnAuditfees & LnTotalfees & LnAuditfees & LnTotalfees \\
\hline \multirow[t]{2}{*}{$\left(\mathrm{EUR}^{*}\right) \mathrm{PsSACORD}$ [2006] } & 0.074 & 0.031 & $0.182 *$ & 0.097 & 0.174 & 0.136 \\
\hline & [0.89] & {$[0.40]$} & {$[1.84]$} & {$[0.78]$} & {$[1.08]$} & [0.91] \\
\hline \multirow[t]{2}{*}{ (EUR*)PsSACORD[2007] } & 0.029 & 0.035 & -0.034 & 0.070 & 0.066 & 0.072 \\
\hline & {$[0.39]$} & {$[0.46]$} & {$[-0.33]$} & {$[0.58]$} & {$[0.47]$} & {$[0.55]$} \\
\hline \multirow[t]{2}{*}{ (EUR*)PsSACORD[2008] } & $0.253 * * *$ & $0.272 * * *$ & $0.190 * *$ & $0.233 * * *$ & $0.120 * *$ & $0.102 * *$ \\
\hline & {$[4.26]$} & [4.17] & {$[2.10]$} & {$[2.61]$} & [2.13] & {$[2.05]$} \\
\hline \multirow[t]{2}{*}{ (EUR*)PsSACORD[2011] } & -0.014 & 0.001 & 0.0145 & 0.004 & $0.098^{*}$ & 0.081 \\
\hline & {$[-0.45]$} & {$[0.02]$} & [0.39] & [0.11] & {$[1.77]$} & [1.61] \\
\hline \multirow[t]{2}{*}{ (EUR*)PsSACORD[2012] } & -0.012 & -0.024 & 0.038 & -0.037 & 0.048 & 0.035 \\
\hline & {$[-0.32]$} & {$[-0.61]$} & {$[-1.20]$} & {$[-1.12]$} & [1.27] & [0.99] \\
\hline Observation & 1164 & 1164 & 706 & 706 & 921 & 921 \\
\hline Adj. R-squared (\%) & 77.12 & 81.22 & 80.23 & 84.24 & 77.36 & 80.12 \\
\hline Controls & YES & YES & YES & YES & YES & YES \\
\hline Firm fixed effects & YES & YES & YES & YES & YES & YES \\
\hline Year fixed effects & YES & YES & YES & YES & YES & YES \\
\hline \multicolumn{7}{|c|}{$\begin{array}{l}\text { NOTES: This table presents the results from regressing audit fees and total fees on indicator } \\
\text { variables for two years following the implementation of the regulation. The regressions include (but } \\
\text { are not reported here) a constant term and control variables used in model } 1 \text { (not reported here for } \\
\text { brevity), and are estimated by difference-in-differences with standard errors that are robust to } \\
\text { heteroscedasticity and clustered at the firm level. The explanatory variables are defined as follows: } \\
\text { (EUR*)PsSACORD[2006] is an indicator variable that equals one for } 2006 \text { financial yearend and } \\
\text { subsequent years; (EUR*)PsSACORD[2007] is an indicator variable that equals one for } 2007 \\
\text { financial yearend and subsequent years; (EUR*)PsSACORD[2008] is an indicator variable that } \\
\text { equals one for } 2008 \text { financial yearend and subsequent years; (EUR*)PsSACORD[2011] is an } \\
\text { indicator variable that equals one for } 2011 \text { financial yearend and the following years; and } \\
\text { (EUR*)PsSACORD[2012] is an indicator variable that equals one for } 2012 \text { financial yearend and } \\
\text { the following years. Matched sample analysis is based on Fiscal Year, size (LnAssets), profitability } \\
\text { (ROA), financial distress (LnSTDCFO), and business risk (Nloans/TA). All other firm } \\
\text { characteristics are as defined in the Appendix. All continuous variables are winsorized at the } 1 \text { st and } \\
99 \text { th percentile. Statistical significance denoted as ***, **, and * for } 1 \%, 5 \% \text { and } 10 \% \text { respectively } \\
\text { (using a two-sided test). }\end{array}$} \\
\hline
\end{tabular}




\begin{tabular}{|c|c|c|c|c|c|c|c|c|c|c|}
\hline WLE S (I A & A) 111 & 110 & 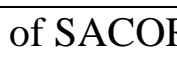 & Do & CDR tas & & IIKS & & & \\
\hline & LnoStk & & LnZ-score & $(\mathbf{r t n})$ & LnZ-score & (roa) & $\pi_{n a \mathrm{i} z}$ & & LnNPI & /TA \\
\hline Columns & (1) & & $(2)$ & & (3) & & (4) & & $(5)$ & \\
\hline & Coeff. & t-stat & Coeff. & t-stat & Coeff. & t-stat & Coeff. & t-stat & Coeff. & $\mathrm{t}$-stat \\
\hline PsSACORD & $0.362 * * *$ & 5.18 & $0.697 * * *$ & 4.60 & $0.223 * * *$ & 3.56 & $0.318 * * *$ & 3.15 & $0.443^{* *}$ & 2.05 \\
\hline IFRS & $0.035^{*}$ & 1.64 & 0.042 & 0.96 & -0.036 & -0.83 & -0.004 & -0.24 & 0.061 & 0.31 \\
\hline FINCRS & $0.405^{* * *}$ & 5.06 & $0.809^{* * *}$ & 4.95 & $0.303 * * *$ & 4.47 & $0.239 *$ & 1.66 & -0.095 & -0.89 \\
\hline Basel II & $0.145 * *$ & 2.46 & $0.266^{* *}$ & 2.23 & $-0.091^{*}$ & -1.84 & 0.016 & 0.23 & $0.399 * *$ & 2.40 \\
\hline LnGeoSegmts & 0.089 & 1.60 & $0.246 * *$ & 2.06 & 0.053 & 0.48 & -0.019 & -0.71 & 0.110 & 1.22 \\
\hline Loss_Ind & $0.480 * * *$ & 6.74 & $1.221 * * *$ & 7.35 & $0.823 * * *$ & 5.50 & $0.243^{* * *}$ & 4.94 & $0.712 * * *$ & 4.72 \\
\hline LnAssets & -0.029 & -1.35 & -0.056 & -1.31 & $-0.080 * *$ & -2.37 & 0.002 & 0.12 & 0.040 & 0.86 \\
\hline LTDebt/TA & -0.001 & -0.64 & -0.006 & -1.22 & -0.004 & -0.89 & 0.001 & 1.23 & -0.011 & -1.56 \\
\hline NLoan/TA & $-0.003 * *$ & -2.47 & $-0.014 * * *$ & -4.35 & $-0.014 * * *$ & -4.09 & 0.000 & -0.27 & 0.001 & 0.12 \\
\hline LnGDPPerCap & $-1.835^{* *}$ & -2.47 & $-3.851 * * *$ & -2.88 & $-1.910 * *$ & -2.06 & -1.718 & -1.36 & -1.958 & -1.54 \\
\hline EconFreedm & 0.010 & 0.92 & 0.041 & 1.49 & -0.007 & -0.20 & -0.006 & -0.31 & $-0.082 * * *$ & -3.25 \\
\hline Tobin’s Q & $0.016^{* * *}$ & 2.80 & $0.217 * * *$ & 10.79 & $0.073 * * *$ & 4.54 & $0.015^{* * *}$ & 3.53 & $0.079 * * *$ & 3.39 \\
\hline LnSTDCFO & 0.020 & 0.82 & 0.042 & 0.73 & $0.200 * * *$ & 2.92 & 0.003 & 0.31 & 0.043 & 0.90 \\
\hline $\mathrm{CFO} / \mathrm{TA}$ & 0.000 & -0.04 & -0.037 & -1.33 & 0.027 & 0.98 & $0.010^{*}$ & 1.85 & $0.086^{*}$ & 1.90 \\
\hline NIR/Rev & 0.230 & 1.32 & 0.343 & 0.94 & -0.684 & -1.45 & -0.014 & -0.11 & 0.447 & 0.84 \\
\hline LnAuditCommN & -0.016 & -0.70 & -0.061 & -1.21 & -0.073 & -1.57 & -0.005 & -0.53 & -0.029 & -0.65 \\
\hline LnAccruals/TA & 0.007 & 0.56 & 0.017 & 0.83 & 0.013 & 0.31 & 0.005 & 0.51 & $0.065^{*}$ & 1.73 \\
\hline Deposit/TA & -0.002 & -1.14 & -0.008 & -1.28 & -0.005 & -1.34 & $-0.003 * *$ & -2.11 & $0.033^{* * *}$ & 5.27 \\
\hline LnInst_Investor & -0.006 & -0.51 & 0.006 & 0.24 & 0.025 & 1.04 & -0.008 & -1.31 & $0.064 * *$ & 2.29 \\
\hline Debt/GDP & -0.000 & -0.33 & -0.002 & -0.97 & 0.001 & 0.98 & -0.000 & -0.09 & -0.006 & -1.52 \\
\hline Intercept & $14.278^{*}$ & 1.91 & 13.281 & 0.96 & 13.226 & 1.38 & $0.319^{* * *}$ & 3.26 & 16.283 & 1.23 \\
\hline No of observations & 1148 & & 1148 & & 1144 & & 1140 & & 951 & \\
\hline Adj. R-squared (\%) & 61.96 & & 78.60 & & 43.96 & & 40.47 & & 73.85 & \\
\hline Firm fixed effects & YES & & YES & & YES & & YES & & YES & \\
\hline Year fixed effects & YES & & YES & & YES & & YES & & YES & \\
\hline $\begin{array}{l}\text { Notes: This table sho } \\
\text { variables are the log } \\
\text { Laeven and Levine ( } \\
\text { stock return volatility } \\
\text { (2008); and nonperfo } \\
\text { other firm characte } \\
\text { and } 99 \text { th percentile } \\
\text { models are estimat } \\
\text { and double cluster } \\
\text { and } 10 \% \text { respective }\end{array}$ & $\begin{array}{l}\text { 009). Multi } \\
\text { (LnsStkrtn) } \\
\text { ming loan } r \\
\text { istics are a } \\
\text { Country a } \\
d \text { by differ } \\
\text { at the firn } \\
\text { y (using a }\end{array}$ & $\begin{array}{l}\text { frod by } \\
\text { from G } \\
\text { atio (NF } \\
\text { define } \\
\text { ad year } \\
\text { ence-in } \\
\text { and y } \\
\text { two-sic }\end{array}$ & $\begin{array}{l}\text { (-1) to make } \\
\text { oetz et al. (2 } \\
\text { L/TA) from } \\
\text { d in the Ap } \\
\text { fixed effec } \\
\text {-differences } \\
\text { ear level. S } \\
\text { ded test). }\end{array}$ & $\begin{array}{l}\text { Berger } \\
\text { ts are } \\
\text { s with } \\
\text { tatistic }\end{array}$ & $\begin{array}{l}\text { efault proba } \\
\text { et al. (2016 } \\
\text { All conti } \\
\text { ncluded in } \\
\text { standard er } \\
\text { al significa }\end{array}$ & $\begin{array}{l}\text { ) are al } \\
\text { nuous } \\
\text { each } r \\
\text { rors th } \\
\text { ance de }\end{array}$ & $\begin{array}{l}\text { Iog value o } \\
\text { higher risk } \\
\pi_{\text {naïve) fro }} \\
\text { o proxies u } \\
\text { variables a } \\
\text { egression } \\
\text { t are robu } \\
\text { noted as } *\end{array}$ & ed for & $\begin{array}{l}\text { The natural } \\
\text { th and Shun } \\
\text { risk taking. } \\
\text { orized at th } \\
\text { reported. T } \\
\text { teroscedas } \\
\text { and * for } 1\end{array}$ & $\begin{array}{l}\text { ent } \\
\text { from } \\
\text { log of } \\
\text { iway } \\
\text { All } \\
\text { e } 1 \text { st } \\
\text { he } \\
\text { city } \\
\%, 5 \%\end{array}$ \\
\hline
\end{tabular}




\begin{tabular}{|c|c|c|c|c|c|c|c|c|c|c|}
\hline \multicolumn{11}{|c|}{ TABLE 5 (PANEL B) The effect of SACORD on risk taking (matched sample) } \\
\hline \multirow{3}{*}{ Columns } & \multirow{2}{*}{\multicolumn{2}{|c|}{$\frac{\text { LnoStkrtn }}{(1)}$}} & \multirow{2}{*}{\multicolumn{2}{|c|}{$\frac{\text { LnZ-score(rtn) }}{(2)}$}} & \multirow{2}{*}{\multicolumn{2}{|c|}{$\begin{array}{c}\text { LnZ-score(roa) } \\
(3)\end{array}$}} & \multirow{2}{*}{\multicolumn{2}{|c|}{$\frac{\pi_{\text {naive }}}{\text { (4) }}$}} & \multirow{2}{*}{\multicolumn{2}{|c|}{$\frac{\text { LnNPL/TA }}{(5)}$}} \\
\hline & & & & & & & & & & \\
\hline & Coeff. & t-stat & Coeff. & t-stat & Coeff. & t-stat & Coeff. & t-stat & Coeff. & t-stat \\
\hline EUR*PsSACORD & $0.154 * * *$ & 2.87 & $0.273^{* *}$ & 2.42 & $0.385 * * *$ & 2.71 & $0.227 * * *$ & 5.39 & 0.085 & 0.55 \\
\hline IFRS & $-0.141 * * *$ & -2.69 & $-0.283 * *$ & -2.43 & 0.049 & 0.26 & -0.010 & -0.36 & 0.029 & 0.17 \\
\hline FINCRS & $0.446^{* * *}$ & 13.09 & $0.875 * * *$ & 12.15 & $0.198 * *$ & 2.06 & $0.118^{* * *}$ & 4.20 & $0.197 *$ & 1.93 \\
\hline Basel II & $0.363 * * *$ & 6.81 & $0.725 * * *$ & 6.37 & 0.188 & 1.23 & $0.068 * *$ & 2.07 & 0.148 & 0.96 \\
\hline LnGeoSegmts & 0.063 & 1.40 & $0.175^{*}$ & 1.86 & -0.052 & -0.35 & -0.008 & -0.20 & -0.033 & -0.26 \\
\hline Loss_Ind & $0.436 * * *$ & 8.79 & $0.999 * * *$ & 9.44 & $0.704 * * *$ & 5.85 & $0.348 * * *$ & 7.10 & $0.799 * * *$ & 6.05 \\
\hline LnAssets & $-0.037 * * *$ & -3.77 & $-0.110 * * *$ & -4.83 & $-0.077 * * *$ & -2.84 & 0.000 & 0.01 & -0.019 & -0.60 \\
\hline LTDebt/TA & -0.003 & -1.41 & $-0.012 * * *$ & -2.93 & -0.006 & -1.05 & -0.001 & -0.35 & -0.004 & -0.55 \\
\hline NLoan/TA & $-0.003 * *$ & -2.11 & $-0.012 * * *$ & -3.62 & $-0.012 * * *$ & -3.27 & -0.002 & -1.29 & 0.002 & 0.43 \\
\hline LnGDPPerCap & $-2.799 * * *$ & -4.75 & $-5.275^{* * *}$ & -4.07 & -2.329 & -1.56 & $-1.352 * * *$ & -3.21 & 1.678 & 1.05 \\
\hline EconFreedm & $0.053 * * *$ & 5.33 & $0.097 * * *$ & 4.34 & $-0.060 *$ & -1.87 & -0.002 & -0.20 & 0.003 & 0.08 \\
\hline Tobin's Q & $0.040 * * *$ & 6.06 & $0.325^{* * *}$ & 17.56 & $0.123^{* * *}$ & 7.15 & $0.026^{* * *}$ & 5.24 & $0.044 * * *$ & 2.44 \\
\hline LnSTDCFO & $0.063 * * *$ & 3.52 & $0.132 * * *$ & 3.37 & $0.243 * * *$ & 4.58 & $0.027^{*}$ & 1.73 & 0.020 & 0.41 \\
\hline $\mathrm{CFO} / \mathrm{TA}$ & 0.013 & 1.02 & $-0.062 * *$ & -2.05 & -0.013 & -0.37 & 0.002 & 0.23 & $0.117 * * *$ & 2.26 \\
\hline NIR/Rev & -0.029 & -0.20 & $-0.509^{*}$ & -1.66 & -0.604 & -1.62 & -0.160 & -1.18 & 0.669 & 1.38 \\
\hline LnAuditCommN & -0.026 & -1.58 & $-0.059 *$ & -1.72 & -0.064 & -1.06 & -0.009 & -0.61 & -0.022 & -0.44 \\
\hline LnAccruals/TA & 0.005 & 0.46 & 0.023 & 0.97 & 0.071 & 1.96 & -0.001 & -0.10 & 0.048 & 1.37 \\
\hline Deposit/TA & -0.001 & -0.89 & -0.003 & -0.84 & -0.008 & -1.83 & -0.002 & -1.42 & $0.023 * * *$ & 4.36 \\
\hline LnInst_Investor & -0.006 & -0.53 & -0.019 & -0.73 & -0.026 & -0.84 & -0.007 & -0.88 & 0.002 & 0.06 \\
\hline Debt/GDP & $0.010 * * *$ & 5.49 & $0.024 * * *$ & 5.82 & -0.003 & -0.50 & $0.004^{* *}$ & 2.36 & $0.036 * * *$ & 7.01 \\
\hline Intercept & $19.126 * * *$ & 3.09 & 14.340 & 1.06 & 17.977 & 1.15 & 12.259 & 2.75 & -26.247 & -1.55 \\
\hline No of observations & 716 & & 716 & & 717 & & 715 & & 715 & \\
\hline Adj. R-squared & 72.31 & & 73.19 & & 36.51 & & 40.65 & & 73.76 & \\
\hline Country fixed effects & YES & & YES & & YES & & YES & & YES & \\
\hline Year fixed effects & YES & & YES & & YES & & YES & & YES & \\
\hline \multicolumn{11}{|c|}{$\begin{array}{l}\text { Notes: This table shows the regression results for the risk taking behaviour of banks post-SACORD. The dependent } \\
\text { variables are the log value of bank Z-score(rtn) from Goetz et al. (2016); natural log value of bank Z-score(roa) from } \\
\text { Laeven and Levine (2009). Multiplied by (-1) to make a larger Z-score reflects a higher risk taking. The natural log of } \\
\text { stock return volatility (LnsStkrtn) from Goetz et al. (2016); default probability ( } \pi_{n a \text { äve }} \text { from Bharath and Shumway } \\
\text { (2008); and nonperforming loan ratio (NPL/TA) from Berger, Imbierowicz and Rauch (2016) are also proxies used } \\
\text { for risk taking. All other firm characteristics are as defined in the Appendix. All continuous variables are winsorized } \\
\text { at the 1st and 99th percentile. Country and year fixed effects are included in each regression but not reported. The } \\
\text { models are estimated by difference-in-differences with standard errors that are robust to heteroscedasticity and double } \\
\text { clustered at the firm and year level. Statistical significance denoted as } * * *, * * \text {, and } * \text { for } 1 \%, 5 \% \text { and } 10 \% \\
\text { respectively (using a two-sided test). }\end{array}$} \\
\hline
\end{tabular}




\begin{tabular}{|c|c|c|c|c|}
\hline & \multicolumn{2}{|c|}{ EU Banks Only } & \multicolumn{2}{|c|}{ Matched Sample } \\
\hline & Chargeoff $_{(t+1)}$ & $\operatorname{EBP}_{(t+1)}$ & Chargeoff $_{(t+1)}$ & $\operatorname{EBP}_{(t+1)}$ \\
\hline & 1 & 2 & 3 & 4 \\
\hline (EUR*)PsSACORD & $0.113 * * *$ & 0.335 & 0.117 & 0.182 \\
\hline & {$[2.87]$} & [0.31] & {$[0.88]$} & [0.36] \\
\hline LLP/TA & -0.019 & & $-0.441 * * *$ & \\
\hline & [1.04] & & [2.95] & \\
\hline (EUR*)PsSACORD*LLP/TA & $0.017^{* * *}$ & & $0.311^{* *}$ & \\
\hline & {$[2.04]$} & & {$[2.33]$} & \\
\hline NPL/TA & $0.062 * * *$ & & $0.091 *$ & \\
\hline & {$[3.70]$} & & {$[1.74]$} & \\
\hline ROA & & $\begin{array}{c}-0.151^{* * * *} \\
{[3.18]}\end{array}$ & & $\begin{array}{c}-0.123 * * * * \\
{[2.78]}\end{array}$ \\
\hline$\left(\right.$ EUR $\left.^{*}\right) \mathrm{PsSACORD*ROA}$ & & $\begin{array}{c}0.208^{* *} \\
{[2.53]}\end{array}$ & & $\begin{array}{c}0.163 * * \\
{[2.36]}\end{array}$ \\
\hline LnTA & $\begin{array}{l}0.009 \\
{[0.10]}\end{array}$ & $\begin{array}{c}-0.081^{*} \\
{[-1.70]}\end{array}$ & $\begin{array}{c}0.290 * * * \\
{[3.70]}\end{array}$ & $\begin{array}{l}-0.129 \\
{[-1.45]}\end{array}$ \\
\hline Intercept & $\begin{array}{l}-0.204 \\
{[-0.11]}\end{array}$ & $\begin{array}{c}3.018 * * * \\
{[3.47]}\end{array}$ & $\begin{array}{c}-5.941 * * * \\
{[3.70]}\end{array}$ & $\begin{array}{l}4.551^{*} \\
{[1.81]}\end{array}$ \\
\hline Number of observations & 978 & 1260 & 732 & 732 \\
\hline R-squared (\%) & 62.57 & 52.23 & 61.71 & 55.59 \\
\hline Year fixed effects & YES & YES & YES & YES \\
\hline Firm fixed effects & YES & YES & YES & YES \\
\hline $\begin{array}{l}\text { Notes: This table presents the } \\
\text { the following models: Charge } \\
\beta_{3}[E U R] * \text { PSSACORD } * L L P \\
\beta_{1}[E U R] * P S S A C O R D+\beta_{2} R \\
\text { Chargeoff } f_{t+1} \text { is loan charge- } \\
E B P_{t+1} \text { is Pre-tax income befo } \\
\text { assets of year } t \text {. PsSACORD is } \\
\text { period for the EU only sample } \\
\text { in the post-SACORD period in } \\
* * * \text { denote significance at } 10 \%, \\
\text { defined in the Appendix. All cc } \\
\text { percentile. }\end{array}$ & $\begin{array}{l}\text { egression result } \\
\text { of } f_{t+1}=\alpha_{t}+ \\
T A_{t}+N P L / T \\
O A_{t}+\beta_{3} E U R \\
\text { offs during year } \\
\text { re provision for } \\
\text { an indicator va } \\
\text { EUR*PsSACC } \\
\text { the EU for the } \\
\% \text { and } 1 \% \text {, respe } \\
\text { ntinuous variabl }\end{array}$ & $\begin{array}{l}\text { of EU banks } \\
\beta_{1}[E U R] * P s \\
+ \text { LnTA } A_{t}+ \\
P S S A C O R D * \\
+1 \text { scaled by } \\
\text { oan loss durit } \\
\text { able that equ } \\
\text { D is an indic } \\
\text { atched samp } \\
\text { ively. All oth } \\
\text { are winsorize }\end{array}$ & $\begin{array}{l}\text { only and matc } \\
S A C O R D+\beta_{2} \\
\varepsilon_{t} \text { and } E B P_{t+1} \\
* R O A_{t}+L n T \\
\text { total assets of } \\
\text { ng year } t+1 \text { sca } \\
\text { als one in the p } \\
\text { cator variable th } \\
\text { le, and zero oth } \\
\text { er firm charact } \\
d \text { at the } 1 \text { st and }\end{array}$ & $\begin{array}{l}\text { d sample for } \\
L P / T A_{t}+ \\
=\alpha_{t}+ \\
+\varepsilon_{t} \text { where } \\
\text { ar } t \text { and } \\
\text { d by total } \\
\text { t-SACORD } \\
\text { equals one } \\
\text { wise. *, **, } \\
\text { istics are as } \\
\text { th }\end{array}$ \\
\hline
\end{tabular}


TABLE 7A The effect of SACORD on compliance costs of large and small banks

\begin{tabular}{lcccc}
\hline & \multicolumn{2}{c}{ EU banks only } & \multicolumn{2}{c}{ Matched Sample } \\
\hline & LnAuditfees & LnTotalfees & LnAuditfees & LnTotalfees \\
\hline & $\mathbf{1}$ & $\mathbf{2}$ & $\mathbf{3}$ & $\mathbf{4}$ \\
\hline PsSACORD/EUR*PsSACORD* & & & & \\
-Large banks & 0.125 & $0.141^{*}$ & $0.189^{* *}$ & $0.222^{* * *}$ \\
& {$[1.18]$} & {$[1.76]$} & {$[2.17]$} & {$[2.78]$} \\
-Small banks & $0.156^{* * *}$ & $0.162^{* *}$ & $0.219^{* *}$ & $0.238^{* *}$ \\
& {$[2.84]$} & {$[2.32]$} & {$[2.30]$} & {$[2.48]$} \\
& & & & \\
Number of observations & 921 & 921 & 706 & 706 \\
Adj. R-squared (\%) & 77.23 & 72.86 & 82.49 & 72.66 \\
& & & & \\
Wald tests for differences across coefficients (p-value): & 0.0041 & 0.0015 & 0.0050 \\
Large/small banks & 0.0002 & & & \\
& & & Yes & Yes \\
Controls & Yes & Yes & Yes & Yes \\
Country fixed effects & Yes & Yes & Yes & Yes \\
Year fixed effects & Yes & Yes & Yes
\end{tabular}

This table presents the effect of SACORD on audit fees and total fees for larger and smaller banks. We classify large banks as banks with total assets above the median value of the sample and smaller banks as those with total assets below the sample median value. The dependent variables are the Natural logarithm of audit fees and total Fees. In estimating columns (1) and (2), PsSACORD is an interaction dummy variable equals to one if the EU bank has implemented SACORD from the adoption year to 2013 and zero otherwise. In estimating columns (3) and (4), EUR*PsSACORD is an interaction dummy variable equals to one if the bank is EU and the period is from the adoption year to 2013. All other firm characteristics are as defined in the Appendix. All continuous variables are winsorized at the 1st and 99th percentile. Country and year fixed effects are included in each regression but not reported. The models are estimated by difference-indifferences with standard errors that are robust to heteroscedasticity and clustered at the firm level. Statistical significance denoted as $* * *, * *$, and $*$ for $1 \%, 5 \%$ and $10 \%$ respectively (using a twosided test). 
TABLE 7B The effect of SACORD on risk taking of large and small banks

\begin{tabular}{|c|c|c|c|c|c|}
\hline & LnoStkrtn & LnZ-score(rtn) & LnZ-score(roa) & $\pi_{\text {naive }}$ & LnNPL/TA \\
\hline & 1 & 2 & 3 & 4 & 5 \\
\hline & \multicolumn{5}{|c|}{ EU banks only } \\
\hline \multicolumn{6}{|l|}{ PsSACORD* } \\
\hline -Large banks & $\begin{array}{c}0.438 * * * \\
{[9.81]}\end{array}$ & $\begin{array}{c}0.752 * * * \\
{[7.74]}\end{array}$ & $\begin{array}{c}0.222 * * * \\
{[3.28]}\end{array}$ & $\begin{array}{c}0.330 * * * \\
{[3.01]}\end{array}$ & $\begin{array}{c}0.755 * * * \\
{[5.85]}\end{array}$ \\
\hline -Small banks & $\begin{array}{c}0.290 * * * \\
{[4.97]}\end{array}$ & $\begin{array}{c}0.676 * * * \\
{[4.96]}\end{array}$ & $\begin{array}{c}0.200 * * \\
{[2.60]}\end{array}$ & $\begin{array}{c}0.248^{* *} \\
{[2.33]}\end{array}$ & $\begin{array}{c}0.145 \\
{[0.97]}\end{array}$ \\
\hline Number of observations & 1148 & 1148 & 1141 & 1140 & 951 \\
\hline Adj. R-squared (\%) & 54.70 & 74.55 & 48.53 & 35.17 & 45.52 \\
\hline \multicolumn{6}{|c|}{ Wald tests for differences across coefficients (p-value): } \\
\hline & \multicolumn{5}{|c|}{ Matched Sample } \\
\hline \multicolumn{6}{|l|}{$\overline{\text { EUR } * \text { PsSACORD* }}$} \\
\hline -Large banks & $\begin{array}{c}0.401 * * * \\
{[4.99]}\end{array}$ & $\begin{array}{c}0.726 * * * \\
{[4.44]}\end{array}$ & $\begin{array}{c}0.335 * * \\
{[2.10]}\end{array}$ & $\begin{array}{c}0.251 * * * \\
{[3.53]}\end{array}$ & $\begin{array}{c}0.624 * * * \\
{[3.31]}\end{array}$ \\
\hline -Small banks & $\begin{array}{c}0.088 \\
{[0.88]}\end{array}$ & $\begin{array}{c}0.198 \\
{[0.94]}\end{array}$ & $\begin{array}{c}0.383 * * \\
{[2.45]}\end{array}$ & $\begin{array}{c}0.237 * * * \\
{[3.40]}\end{array}$ & $\begin{array}{c}0.059 \\
{[0.34]}\end{array}$ \\
\hline Number of observations & 715 & 715 & 716 & 714 & 714 \\
\hline Adj. R-squared (\%) & 66.27 & 78.25 & 29.99 & 40.60 & 42.94 \\
\hline \multicolumn{6}{|c|}{ Wald tests for differences across coefficients (p-value): } \\
\hline Larger/smaller banks & 0.0000 & 0.0000 & 0.0480 & 0.0000 & 0.0018 \\
\hline Controls & Yes & Yes & Yes & Yes & Yes \\
\hline Country fixed effects & Yes & Yes & Yes & Yes & Yes \\
\hline Year fixed effects & Yes & Yes & Yes & Yes & Yes \\
\hline
\end{tabular}

This table presents the effect of SACORD on risk taking for larger and smaller banks. We classify large banks as banks with total assets above the median value of the sample and smaller banks as those with total assets below the sample median value. The dependent variables are the log value of bank Z-score(rtn) from Goetz et al. (2016); natural log value of bank Z-score(roa) from Laeven and Levine (2009). Multiplied by (-1) to make a larger Z-score reflects a higher risk taking. The natural $\log$ of stock return volatility (LnsStkrtn) from Goetz et al. (2016); default probability ( $\pi_{\text {naïve) }}$ from Bharath and Shumway (2008); and nonperforming loan ratio (NPL/TA) from Berger et al. (2016) are also proxies used for risk taking. In estimating columns (1) to (5), PsSACORD is an interaction dummy variable equals to one if the EU bank has implemented SACORD from the adoption year to 2013 and zero otherwise. For the matched sample, in estimating columns (1) to (5),

EUR*PsSACORD is an interaction dummy variable equals to one if the bank is EU and the period is from the adoption year to 2013 All other firm characteristics are as defined in the Appendix. All continuous variables are winsorized at the 1st and 99th percentile. Country and year fixed effects are included in each regression but not reported. The models are estimated by difference-in-differences with standard errors that are robust to heteroscedasticity and double-clustered at the firm and year level. Statistical significance denoted as $* * *, * *$, and $*$ for $1 \%, 5 \%$ and $10 \%$ respectively (using a two-sided test). 
TABLE 7C The effect of SACORD on reporting quality of large and small banks

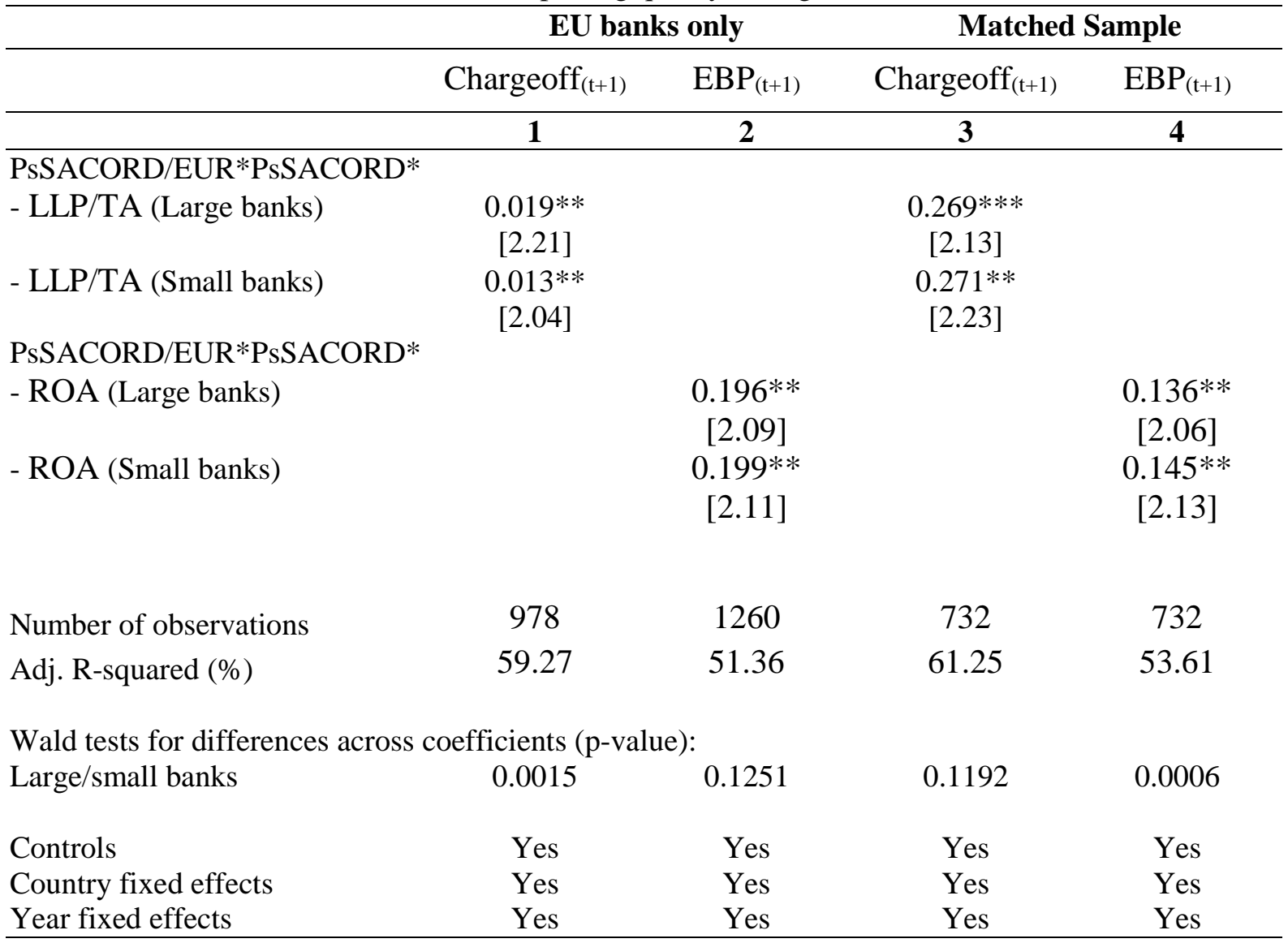

This table presents the effect of SACORD on loan charge-offs $\left(\right.$ Chargeof $\left.f_{t+1}\right)$ and Pre-tax income before provision for loan loss $\left(E B P_{t+1}\right)$ during year $t+1$ scaled by total assets of year $t$ for larger and smaller banks. We classify large banks as banks with total assets above the median value of the sample. In estimating (1) and (2), PsSACORD is an interaction dummy variable equals to one if the EU bank has implemented SACORD from the adoption year to 2013 and zero otherwise. In estimating (3) and (4), EUR*PsSACORD is an interaction dummy variable equals to one if the bank is EU and the period is from the adoption year to 2013. All other firm characteristics are as defined in the Appendix. All continuous variables are winsorized at the 1st and 99th percentile. Country and year fixed effects are included in each regression but not reported. The models are estimated by difference-in-differences with standard errors that are robust to heteroscedasticity and doubleclustered at the firm and year level. Statistical significance denoted as ***, **, and * for $1 \%, 5 \%$ and $10 \%$ respectively (using a two-sided test). 